\title{
11. PALYNOLOGICAL DELINEATION AND REGIONAL CORRELATION OF LOWER THROUGH UPPER MIOCENE SEQUENCES IN THE CAPE MAY AND ATLANTIC CITY BOREHOLES, NEW JERSEY COASTAL PLAIN ${ }^{1}$
}

\author{
Laurent de Verteuil ${ }^{2}$
}

\begin{abstract}
Dinocyst and strontium isotopic stratigraphies from two boreholes are integrated to develop a fine chronology for the lower through upper Miocene succession in New Jersey. These results represent the best constrained and most detailed subdivision of New Jersey Miocene strata to date, including the first confirmed record of upper Miocene deposits in the New Jersey Coastal Plain. The latter is based on dinocyst stratigraphy calibrated to the 1995 Neogene time scale of Berggren and co-authors (Zone DN8; 11.0 to 8.5 m.y.), and appears to date the early development of a proto-Delaware River system.

More specifically, 16 third-order stratigraphic sequences are delineated in the New Jersey Miocene succession. There is excellent agreement between $\mathrm{Sr}$-isotopic ages and independently derived dinocyst datums for the nine lower to lower middle Miocene sequences (Kw0 to Kw3a). The Kw0 sequence contains the oldest known Miocene sediments in the middle Atlantic coastal plain ( 23.6 m.y.) and represents the basal Miocene transgression following the well-established and widespread latest Oligocene regression. Within the upper middle Miocene, Sr-isotopic ages are consistently younger than those inferred from dinocysts (by $\sim 1.5$ m.y.; Kw3b and Ch1 sequences); this calibration problem is due to unresolved complexities in global geochronology. The upper Miocene New Jersey chronology is based solely on dinocyst stratigraphy and comprises four sequences delineated at the Cape May Site only (Ch3 to Ch6).

Direct dinocyst correlations permit the first detailed comparison of this record with classic neritic sequences in Maryland and Virginia. There are clear one-to-one equivalents for most sequences but the upper Miocene correlations need refinement. The integration of the Salisbury Embayment and New Jersey records yields 19 third-order Miocene sequences of 0.2-1.0 m.y. duration. Most intrasequence hiatuses are $0.1-0.5$ m.y. duration; the only notable exception is the $\sim 1.5$ m.y. Kw0/Kw1a hiatus (22.2-20.8 m.y.).

Second-order glacioeustatic trends inferred from $\delta^{18} \mathrm{O}$ records agree in timing and magnitude with lithostratigraphic relationships in the coastal plain: lower Miocene paleoenvironments deepen upsection to a maximum in the Kw2c/SE5 sequence $\left(\sim 14.5 \mathrm{~m} . \mathrm{y}\right.$.); the major $13.0-14.5 \delta^{18} \mathrm{O}$ increase is marked by successive regressive facies relationships, culminating with the onset of deposition of the Choptank and Cohansey formations ( $\sim 13$ m.y.). Comparison of the $\delta^{18} \mathrm{O}$ proxy of third-order glacioeustasy (e.g., Mi1-Mi7 events) with the Miocene sequences suffers from calibration and resolution problems that still confront both systems. The uneven correlation is nevertheless sufficiently good to suggest the primacy of glacioeustasy for determining the timing and architecture of Miocene sequences on the U.S. Atlantic Margin.

Two dinocyst datums, the lowest occurrence of Exochosphaeridium insigne and highest occurrence of Cordosphaeridium cantharellus, are used to divide the Sumatradinium soucouyantiae Interval Zone into three subzones (DN2a, DN2b, and DN2c).
\end{abstract}

\section{INTRODUCTION}

The New Jersey Sea Level Transect project was undertaken to recover, date, and characterize Oligocene to Neogene icehouse sequences beneath the modern coastal plain and continental shelf/slope (Miller and Mountain, 1994). Dinoflagellate cysts (dinocysts) provide the primary Neogene biostratigraphic control at transect sites. De Verteuil and Norris (1996a) calibrated dinocyst events in the Baltimore Canyon Trough and Salisbury Embayment to the Cenozoic time scale of Berggren et al. (1995; hereafter BKSA95) by integrating dinocyst stratigraphy, calcareous biostratigraphy, strontium isotopic ( $\mathrm{Sr}$ ) stratigraphy, magnetostratigraphy and well log and seismic stratigraphy from the Salisbury Embayment and Ocean Drilling Program (ODP) Leg 150 sites (see Mountain, Miller, Blum, Poag, and Twichell, 1996). Consistent dinocyst stratigraphies and excellent core-to-seismic ties permit confident site-to-site sequence correlations and allowed de Verteuil and Norris (unpubl. data) to develop a Miocene sequence chronostratigraphic framework for the New Jersey continental slope and shelf.

${ }^{1}$ Miller, K.G., and Snyder, S.W. (Eds.), 1997. Proc. ODP, Sci. Results, 150X: College Station, TX (Ocean Drilling Program).

${ }^{2}$ Department of Geology, Earth Sciences Centre, University of Toronto, 22 Russell Street, Toronto, Ontario, M5S 3B1, Canada. (Present address: Geological Services Laboratory, Petroleum Company of Trinidad and Tobago Limited, Pointe-à-Pierre, Trinidad, West Indies.) devert@ petrotrin.com
Transect drilling onshore in the New Jersey coastal plain targeted the proximal expression of the Oligocene-Miocene sequence record on this margin (Miller, et al., 1994a, 1996a; Fig. 1). In this paper, I integrate dinocyst stratigraphy with Sr-isotopic ages from Sugarman et al. (Chapter 12, this volume) to develop a chronology for Miocene sequences in the Cape May and Atlantic City boreholes (Figs. 2-4). I show that lower to middle Miocene deltaic sequences in the two boreholes (Kw1, Kw2, etc.; Miller et al., Chapter 14, this volume), as well as newly delineated upper Miocene sequences, are time-equivalent with classic shallow marine to marginal marine sequences in Maryland and Virginia (Fig. 5). Comparing the record from these two depositional systems with Miocene $\delta^{18} \mathrm{O}$ zones of Miller et al. (1991; Fig. 5 ), suggests that the timing of development and relative paleodepths of sequences on the United States' Atlantic margin is controlled by second-order and third-order glacioeustasy and is relatively independent of sediment supply. The Miocene sequences discussed in this paper can also be correlated, through dinocyst stratigraphy (de Verteuil and Norris, 1992, 1996a, unpubl. data), to the regional framework of seismic sequences offshore New Jersey (Greenlee et al., 1988, 1992; Mountain, Miller, Blum, Poag, and Twichell, 1996).

\section{MATERIALS AND METHODS}

Primary dinocyst data for this study come from analyses of 124 core samples from the Cape May and Atlantic City boreholes (Fig. 1; 
Figure 1. Map of the middle United States Atlantic Coastal Plain showing localities discussed in the text. The inset of the Calvert Cliffs area is enlarged by a factor of 3.4 .

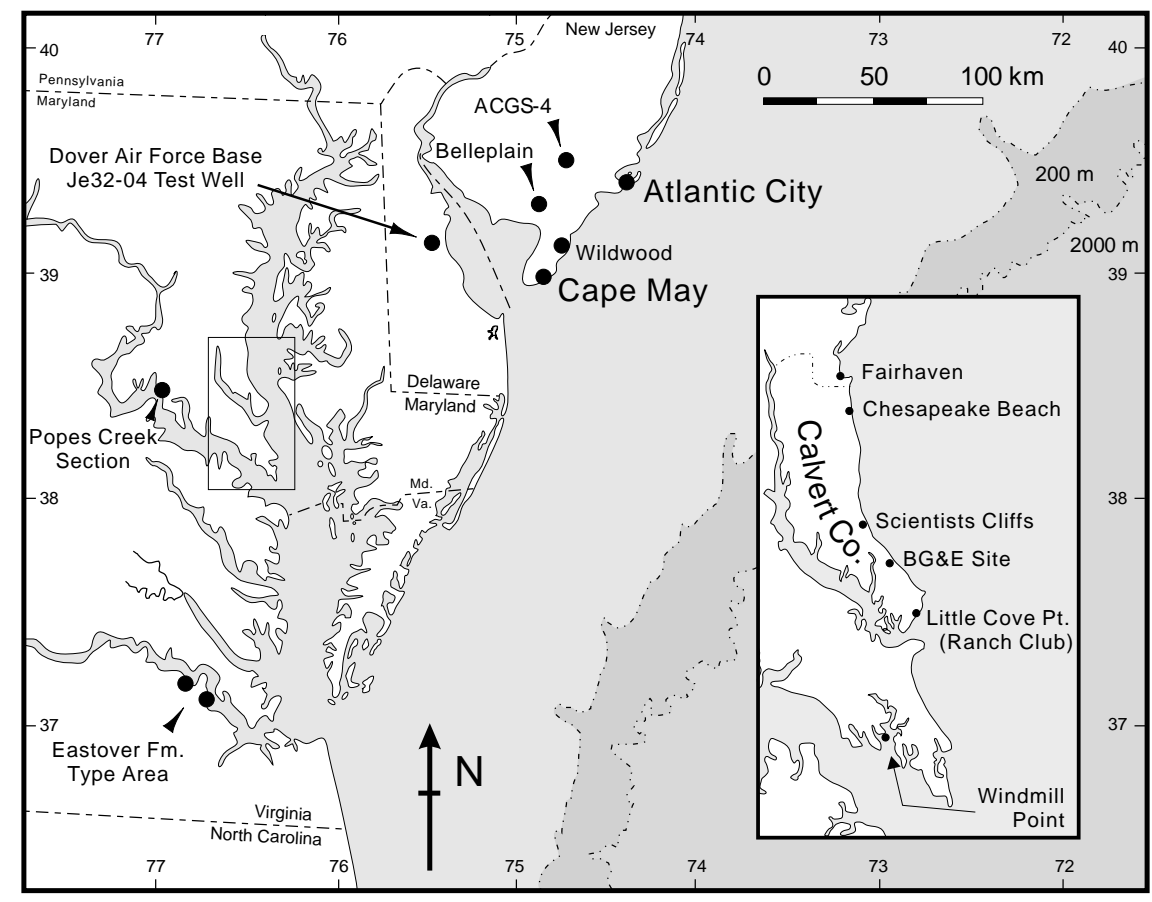

Tables 1,2 ). The Cape May site is at $38^{\circ} 56.52^{\prime} \mathrm{N}, 74^{\circ} 53.00^{\prime} \mathrm{W}$ (Miller, et al., 1996a) and the Atlantic City site at $39^{\circ} 22.42^{\prime} \mathrm{N}, 74^{\circ} 25.24^{\prime} \mathrm{W}$ (Miller, et al., 1994a). Sample numbers indicate their level in feet in the borehole as logged.

For each sample, between 10 and $30 \mathrm{~g}$ of dried sediment was treated with $20 \% \mathrm{HCl}$ for at least $2 \mathrm{hr}$ at room temperature and pressure (rtp), $45 \% \mathrm{HF}$ for at least $5 \mathrm{hr}$ at rtp, followed by $2 \mathrm{hr}$ in $10 \% \mathrm{HCl}$ in a $\sim 85^{\circ} \mathrm{C}$ water bath. Samples were washed to neutrality with distilled water before addition of each successive reagent. One Lycopodium spore tablet (batch \#710961) was added to each sample at the start of acid maceration. Residues were subjected to 30 to 45 seconds in an ultrasonic bath (Blackman HT1.9 tank, at $23 \mathrm{kHz}$ ) and then sieved at $15 \mu \mathrm{m}$ using Nitex (nylon) screen. Residues were stained and mounted as described in de Verteuil and Norris (1996a).

The abundance of specimens in slides scanned using a $25 \times$ objective is categorized qualitatively as follows: rare = taxon occurs in the assemblage, although specimens are seldom encountered when scanning a slide; present $=$ at least one specimen is encountered in four short-axis traverses of a slide; common $=\mathrm{a}$ few specimens are encountered in one short-axis traverse of a slide; abundant = at least one specimen is encountered in most fields of view.

The dinocyst taxa used to determine stratigraphic relations in the two boreholes are tabulated (Tables 1,2). Dinocyst events are recorded as lowest occurrences (LOs) or highest occurrences (HOs). Age relationships for each borehole were determined using the dinocyst zonation of de Verteuil and Norris (1996a) as calibrated to the BKSA95 time scale, augmented by Sr-isotopic age estimates (Sugarman et al., Chapter 12, this volume). Dinocyst taxonomy follows de Verteuil and Norris (1996a, 1996b, 1996c).

\section{RESULTS Dinocyst Stratigraphy}

\section{Cape May}

One hundred samples were analyzed from the upper Cenozoic interval of the Cape May borehole (Fig. 4; Table 1). Almost all the samples were productive, although dinocyst diversity in most samples is moderate to low. Preservation varies from good to poor.
De Verteuil and Norris (1996a) used the HO of Distatodinium biffii to define the base of the Chiropteridium galea Zone (DN1) which spans the Oligocene/Miocene boundary. The upper boundary of Zone DN1 is defined by the HO of Chiropteridium galea. Distatodinium biffii is present only in one sample (CM1295; $394.7 \mathrm{~m}$ ), so that in the Cape May borehole Zone DN1 is provisionally delineated over $208.5 \mathrm{ft}(63.6 \mathrm{~m})$ between samples CM1284.7 and CM1076.2 (391.6 and $328 \mathrm{~m}$ ). In general, Homotryblium vallum/plectilum complex, Apteodinium spp., Spiniferites spp., and Operculodinium centrocarpum group are common in assemblages in Zone DN1 and few taxa have their LOs within this interval.

By integrating limited Sr-isotopic and planktonic foraminiferal data, Miller et al. (1996b) estimated the position of the Oligocene/ Miocene boundary at an unconformable lithic break at $1180 \mathrm{ft}(359.7$ m; Fig. 4). The only dinocyst event associated with this horizon is the HO of Deflandrea phosphoritica in sample CM1183.2 (360.6 m). Elsewhere, Deflandrea phosphoritica ranges into the lower lower Miocene (Brinkhuis et al. 1992; de Verteuil, 1996); its absence in the upper part of Zone DN1 in the Cape May borehole is, therefore, presumably the result of an unsuitable paleoenvironment.

The HO of Chiropteridium galea in sample CM1076.2 (328 m) delineates the upper boundary of Zone DN1, close to an unconformable lithic break at $1062 \mathrm{ft}$ (323.7 m; Fig. 4). The HOs of Caligodinium amiculum, Homotryblium vallum/plectilum complex, and Membranophoridium aspinatum are slightly lower, in sample CM1093.5 (333.3 m). Dinocysts are rare in sample CM1067.4 $(325.3 \mathrm{~m})$, below the $1062 \mathrm{ft}(323.7 \mathrm{~m})$ unconformity, and the absence of Chiropteridium galea in the low diversity assemblage may be the result of preservational bias.

The Sumatradinium soucouyantiae Zone (DN2) is present in the Cape May borehole over a 292.4-ft (89.1 m) interval from 1067.4 to $775 \mathrm{ft}$ (325.3-236.2 m; samples CM1067.4 to CM775). The most common taxa in Zone DN2 are Lingulodinium machaeophorum, Spiniferites spp., Operculodinium spp., and Systematophora placacantha. In the lower part of Zone DN2, Polysphaeridium zoharyi is present over a $100 \mathrm{ft}(30.5 \mathrm{~m})$ interval (samples CM1037.5 to CM937.1; 316.2-285.6 m), which represents its lowest occurrence at this site. At the base of Zone DN2, in sample CM1061 (323.4 m), Apteodinium spiridoides and Cribroperidinium tenuitabulatum are common, and Impagidinium minor begins a stratigraphically re- 


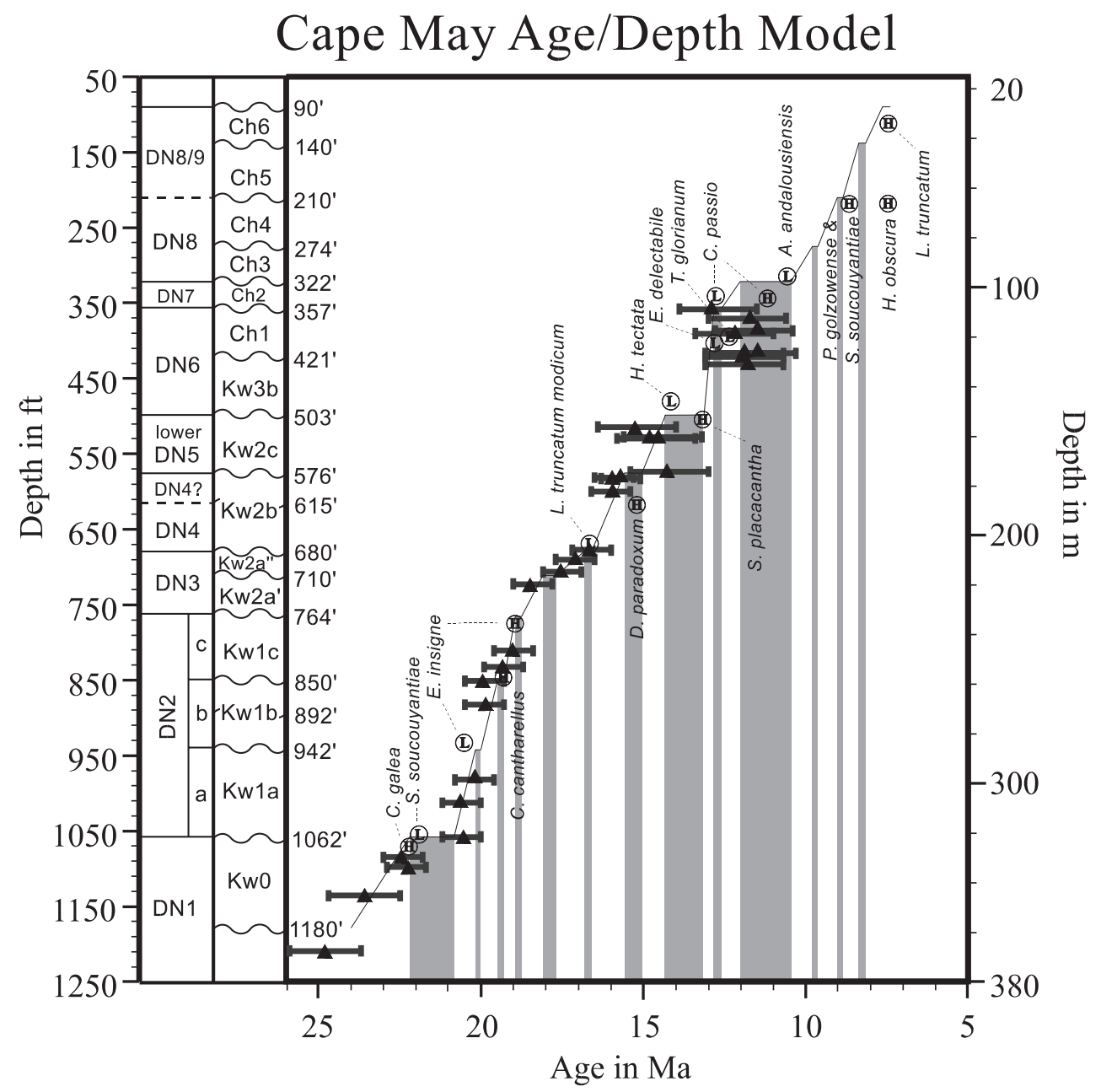

Figure 2. Age/depth model for the Cape May borehole integrating dinocyst stratigraphy with Sr-isotopic ages from Sugarman et al. (Chapter 12, this volume). Circled "L" indicates a dinocyst lowest occurrence (LO) and circled " $\mathrm{H}$ " indicates a highest occurrence (HO) for this borehole. Hiatuses are indicated by doglegs on the line of correlation and are represented by gray bars. The first column on the left shows the dinocyst zones, and the second shows the unconformable stratigraphic breaks and informal sequence terminology.

stricted showing. The overlying sample at $1056.5 \mathrm{ft}$ (322 m) yielded common Membranilarnacia? picena and the LO of Sumatradinium soucouyantiae; the latter is an excellent marker for the base of Zone DN2. In the lower part of Zone DN2, the LO of Cerebrocysta satchelliae in sample CM1025.8 (312.7 m) and the LO of Sumatradinium hamulatum in sample CM1013.2 (308.8 m) are also noteworthy.

Sample CM937.1 (285.6 m) lies above an unconformity at about $942 \mathrm{ft}(287.1 \mathrm{~m})$ and yielded the LO of Exochosphaeridium insigne. The HO of Cordosphaeridium cantharellus is $\sim 90 \mathrm{ft}(27.4 \mathrm{~m})$ higher in sample CM846.6, close to a major unconformable lithic break at $850 \mathrm{ft}(259 \mathrm{~m})$. The HO of Stoveracysta conerae is also in sample CM846.6 (258 m) and the HO of Cerebrocysta satchelliae is in the overlying sample CM837 (255.1 m). The upper boundary of Zone DN2 is delineated by the $\mathrm{HO}$ of Exochosphaeridium insigne in sample CM775 (236.2 m), just below the unconformity at $764 \mathrm{ft}(232.9)$.

The concurrent range of Exochosphaeridium insigne and Cordosphaeridium cantharellus is an important chronostratigraphic event in the middle Atlantic Coastal Plain and Baltimore Canyon Trough (Mountain, Miller, Blum, et al., 1994; de Verteuil and Norris, 1996a, unpubl. data). Consequently, three informal subzones of the Sumatradinium soucouyantiae Interval Zone (DN2) are defined herein (Fig. 5). Subzone DN2a is the interval from the HO of Chiropteridium galea to the LO of Exochosphaeridium insigne. Subzone
DN2b is the interval between the LO of Exochosphaeridium insigne and the $\mathrm{HO}$ of Cordosphaeridium cantharellus. Subzone DN2c is the interval between the $\mathrm{HO}$ of Cordosphaeridium cantharellus and the $\mathrm{HO}$ of Exochosphaeridium insigne.

The Cousteaudinium aubryae Zone (DN3) is a "gap" zone between the HO of Exochosphaeridium insigne and the LO of Labyrinthodinium truncatum. In the Cape May borehole, Zone DN3 was delineated in an 84-ft-thick (25.6 m), unconformity-bound unit between 764 and $680 \mathrm{ft}$ (232.6 and $208.5 \mathrm{~m}$; samples CM763.2 to CM684). Cousteaudinium aubryae has an acme in the upper part of Zone DN3 in samples CM701.2 and CM697 (213.7 and 212.4 m). Zone DN3 in the Cape May borehole is otherwise noteworthy only for the premature $\mathrm{HO}$ of Apteodinium spiridoides in sample CM701.2 (Table 1); this species usually ranges into the upper part of Zone DN4 in this region (de Verteuil and Norris, 1996a; de Verteuil, 1996).

The LO of Labyrinthodinium truncatum modicum in sample CM673 (205.1 m) marks the base of the Distatodinium paradoxum Zone (DN4), which extends for $55 \mathrm{ft}(16.8 \mathrm{~m})$ to the HO of Distatodinium paradoxum in sample CM618 (Table 1). The most common taxa in Zone DN4 are Lingulodinium machaeophorum, Operculodinium centrocarpum group, Spiniferites spp., and Systematophora placacantha. 


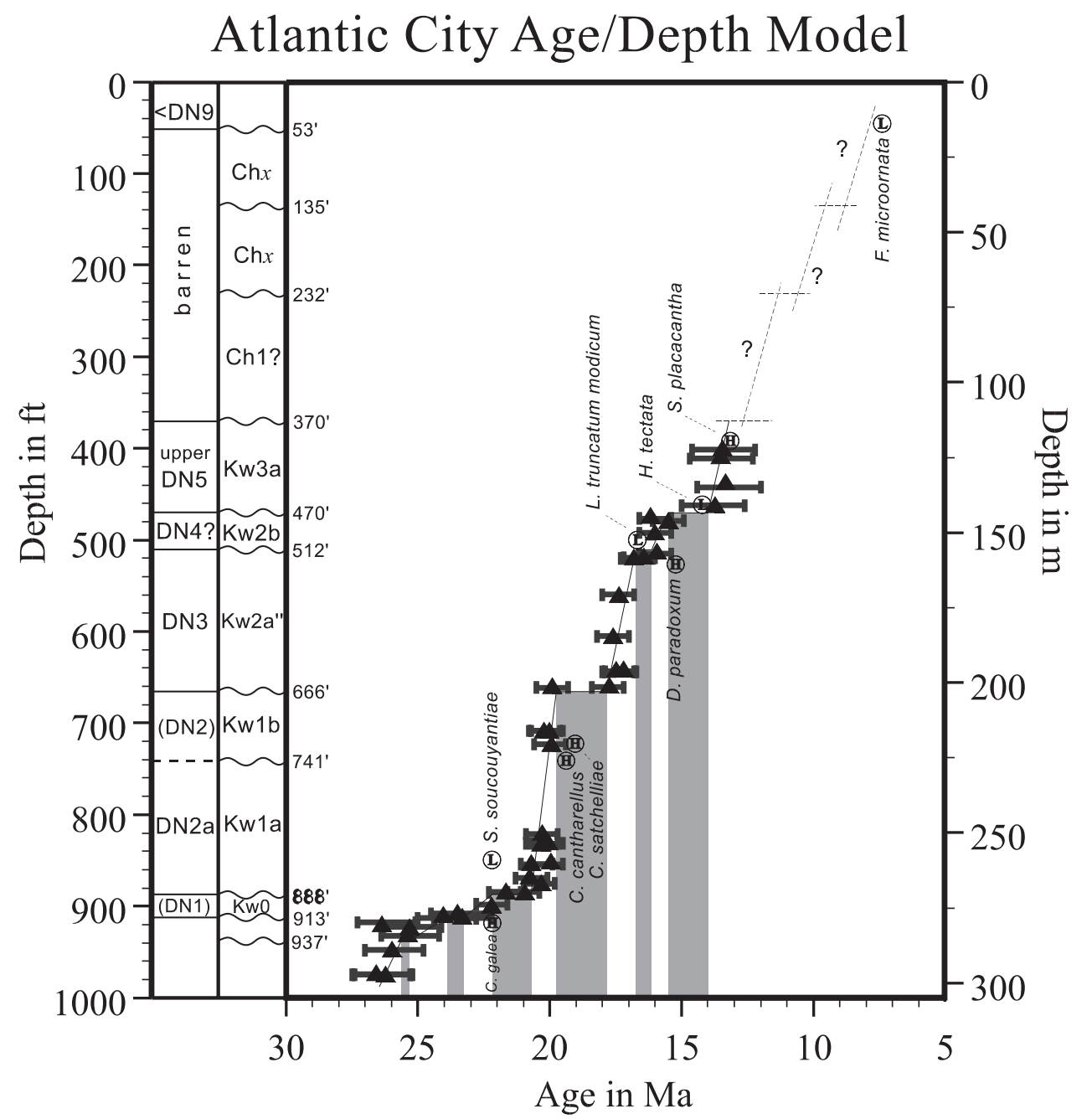

Figure 3. Age/depth model for the Atlantic City Borehole integrating dinocyst stratigraphy with Sr-isotopic ages from Sugarman et al. (Chapter 12, this volume). Circled "L" indicates a dinocyst lowest occurrence (LO) and circled "H" indicates a highest occurrence (HO) for this borehole. Hiatuses are indicated by doglegs on the line of correlation and are represented by gray bars. The first column on the left shows the dinocyst zones, and the second shows the unconformable stratigraphic breaks and informal sequence terminology.

The interval between 615 and $576 \mathrm{ft}(187.5$ and $175.6 \mathrm{~m})$ in the Cape May borehole is marked by sandy facies and poor core recovery (Miller, et al., 1996a). A single sample from within this interval (CM610; $185.9 \mathrm{~m}$ ) contained a lean, nondiagnostic dinocyst assemblage. Thus, additional sampling may confirm the present provisional inclusion of this interval in Zone DN4 (Fig. 4).

The upper boundary of the Batiacasphaera sphaerica Zone (DN5) in the Cape May borehole is clearly delineated by the HO of Systematophora placacantha in sample CM515 $(157 \mathrm{~m})$. This level also marks the $\mathrm{HO}$ of Apteodinium tectatum. The latter event, combined with the absence of Habibacysta tectata, which has its FAD in the upper half of the zone (de Verteuil and Norris, 1996a), indicates that only the lower part of Zone DN5 is present in the Cape May borehole. Specimens of the Cyclopsiella elliptica/granosa complex are present to common within the 103 -ft-thick $(31.4 \mathrm{~m})$ Zone DN5 interval.

The Selenopemphix dionaeacysta Zone (DN6) is another "gap" zone, corresponding to the interval between the HO of Systematophora placacantha and the LO of Cannosphaeropsis passio. In the Cape May borehole, Zone DN6 was delineated over a 140-ft-thick (42.7 m) interval between samples CM497.2 and CM358 (151.5 and $109.1 \mathrm{~m}$; Fig. 4; Table 1). This interval comprises two coarsening-upward cycles, the lower of which is more clay-rich than the upper, separated by an unconformity at approximately $420 \mathrm{ft}$ (128 m; Fig. 4; Miller et al., Chapter 14 , this volume). The lower cycle contains some noteworthy dinocyst datums including the LOs of Trinovantedinium harpagonium and Trinovantedinium papulum in sample CM497.2 (151.5 $\mathrm{m}$ ), the LO of Habibacysta tectata in sample CM484.5 (147.7 m), and the LO of Nematosphaeropsis rigida in sample CM433 (132 m). The Cyclopsiella elliptica/granosa complex is present to common in this lower cycle and has its HO for the borehole in sample CM417.5 (127.3 m). The upper Zone DN6 cycle contains the LO of Erymnodinium delectabile in sample CM405 and the LO of Trinovantedinium glorianum in sample CM396 (120.7 m; Table 1). Providing that the LO of Cannosphaeropsis passio in sample CM347 $(105.8 \mathrm{~m})$ is not delayed, the last two datums represent downward range extensions from de Verteuil and Norris' (1996a) records for the Baltimore Canyon Trough and Salisbury Embayment (but see chronology discussion below; Fig. 2).

A single sample from $347 \mathrm{ft}(105.8 \mathrm{~m})$ belongs to the Cannosphaeropsis passio Zone (DN7), based on the presence of rare specimens of the eponymous species in sample CM347. The overlying sample CM341.5 (104 m) contains a marginal marine assemblage that does not include Cannosphaeropsis passio. The next higher three 


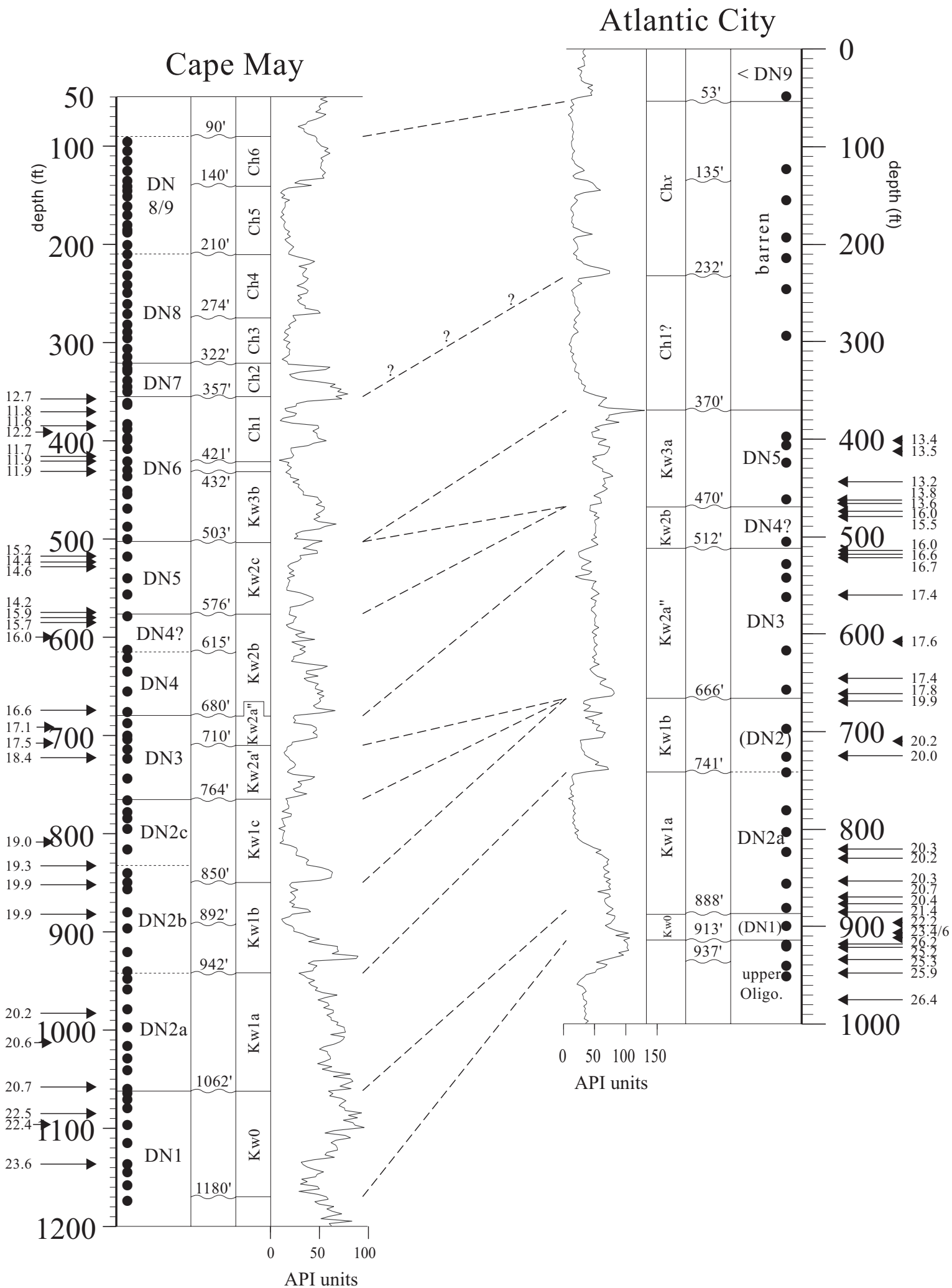

Figure 4. Integrated stratigraphic correlation for the Cape May and Atlantic City boreholes, based on dinocysts, Sr-isotopes, lithology, disconformities, and geophysical logs. All depths are in feet; black dots show the positions of palynology samples in Tables 1 and 2. Individual columns show dinocyst zones, depths of disconformity surfaces, and informal sequences terminology. Bracketed dinocyst zones indicate that the presence of the zone is inferred, although the zonal taxa were not recorded. Values for Sr-isotopic ages from Sugarman et al. (Chapter 12, this volume) are indicated by horizontal arrows at the level of sampling. The correlations shown are discussed in the text. 


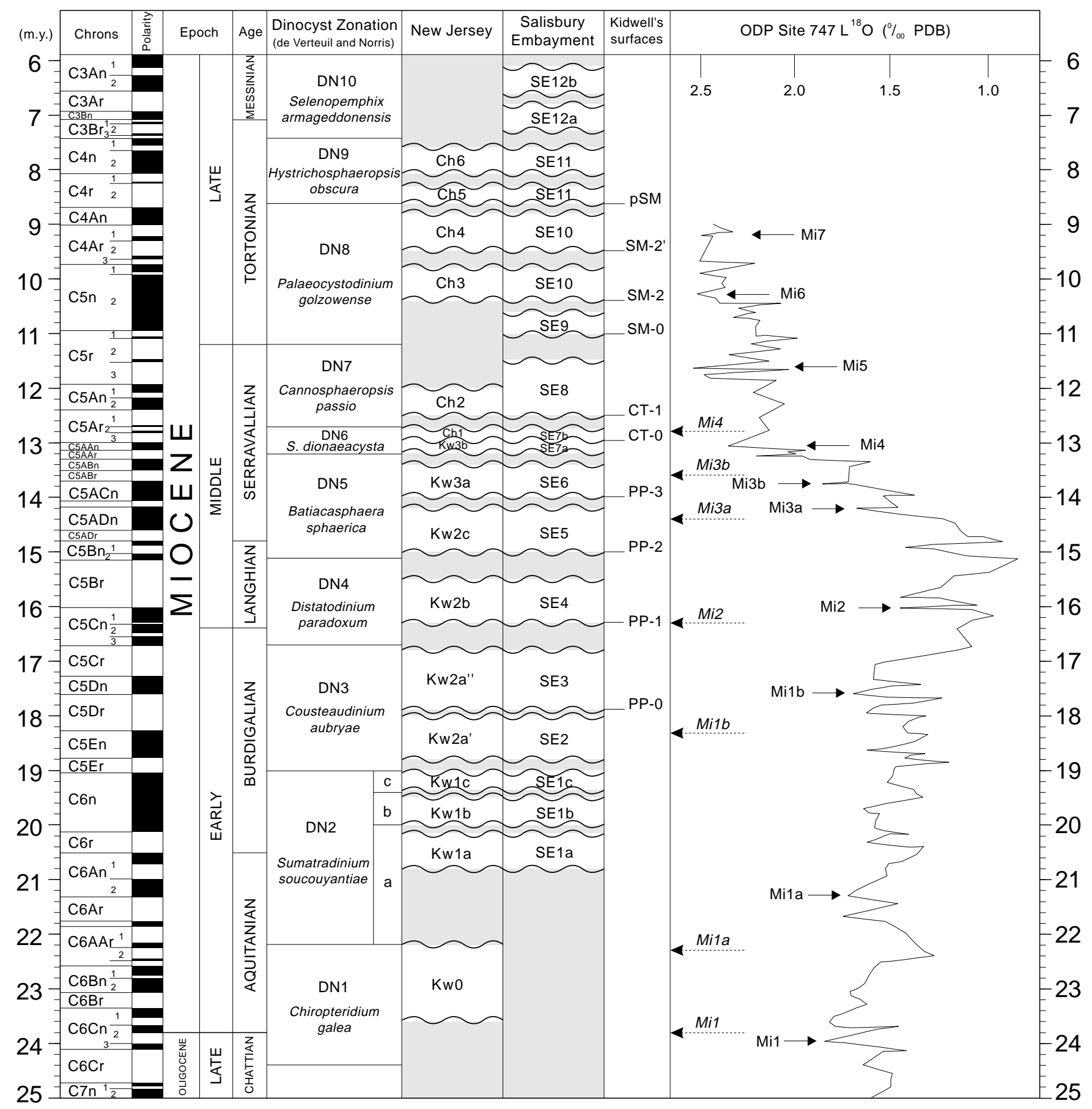

Figure 5. Integrated Miocene allostratigraphy for the middle U.S. Atlantic Coastal Plain, showing the temporal relationships between the composite sequence records of New Jersey and Maryland/Virginia, based on this study and de Verteuil and Norris (1996a). The unconformity/sequence terminology of Kidwell $(1984,1989,1997)$ is shown in relation to the sequences discussed herein. Coastal plain sequences are plotted against the Berggren et al. (1995) time scale using the combined dinocyst and strontium age estimates derived from this study and from de Verteuil and Norris (1996a). The calibration of dinocyst zones to BKSA95 follows de Verteuil and Norris (1996a). The record of coastal plain sequences is compared at right with the time-adjusted $\delta^{18} \mathrm{O}$ isotopic record from ODP Site 747 (Oslick et al., 1994). Dashed arrows at the left of the column represent $\delta^{18} \mathrm{O}$ increase inflection points reported in Miller et al. (Chapter 14, this volume) from a stacked and smoothed composite of Atlantic $\delta^{18} \mathrm{O}$ records. 
samples (CM335.2, CM326, and CM323; 102.2, 99.4, and $98.5 \mathrm{~m}$ ) are from a lignitic nonmarine interval barren of dinoflagellates. All five samples belong to a shallowing-upward unconformity-bound unit between 357 and $322 \mathrm{ft}$ in the Cape May borehole (108.8 and $98.1 \mathrm{~m}$; Miller, et al., 1996a).

The interval between 318 and $217 \mathrm{ft}$ ( 96.9 and $66.1 \mathrm{~m}$ ) belongs to the Palaeocystodinium golzowense Zone (DN8). The upper boundary of Zone DN8 is marked by the HO of Sumatradinium soucouyantiae in sample CM217. This event and the HO of Palaeocystodinium golzowense in the same sample may be slightly premature as a result of the increasingly marginal marine nature of the depositional environments. The HOs of Erymnodinium delectabile and Hystrichosphaeropsis obscura, also in sample CM217, are clearly premature, because the usually coeval $\mathrm{HO}$ of Labyrinthodinium truncatum is significantly higher in sample CM112 (34.1 m). At the base of the Zone DN8 interval the LOs of Achomosphaera andalousiensis, Geonettia clineae, and a new species Pyxidinopsis are in sample CM318 (96.9 m).

There are two distinct sedimentation cycles within the Zone DN8 interval that are clearly delineated on the lithologic and gamma-ray logs (Fig. 4; Miller, et al., 1996a). The boundary between them is marked by a pebble bed and unconformity at $274 \mathrm{ft}(83.5 \mathrm{~m})$. In the lower cycle, Polysphaeridium zoharyi is present in significant amounts and Geonettia clineae is rare or absent; in the upper cycle the situation is reversed (Table 1).

The remainder of the sampled interval, from $\sim 210$ to $90 \mathrm{ft}$ (64$27.4 \mathrm{~m}$ ), belongs to the middle upper Miocene. The premature $\mathrm{HO}$ of Hystrichosphaeropsis obscura in sample CM217 (66.1 m) prevents formal delineation of the Hystrichosphaeropsis obscura Zone (DN9) in the Cape May borehole. The presence of Labyrinthodinium truncatum modicum in sample CM112 (34.1 m), however, indicates that this level is not younger than Zone DN9 (de Verteuil and Norris, 1996a). In view of the environmentally truncated range tops in sample CM217 and the absence of taxa such as Barssidinium evangelineae and Operculodinium? eirikianum, which regionally first appear in Zone DN9, the interval from samples CM207 to CM92 (63.1-28 $\mathrm{m})$ is here delineated as undifferentiated Zone DN8/9.

The undifferentiated Zone DN8/9 interval comprises two distinct cycles recognizable on the basis of lithology and gamma-ray log response (Fig. 4; Miller, et al., 1996a). The lower cycle consists of interbedded muddy sands and cleaner sands and extends to the unconformity at $140 \mathrm{ft}(42.7 \mathrm{~m})$. Dinocyst diversity is low in this unit (samples CM207, CM197, CM185, CM176.9, CM166.9, CM158, CM148, and CM142) and Polysphaeridium zoharyi is the only species that is consistently present. The base of the overlying cycle is marked by a coarse sand and pebble bed that grades rapidly into a carbonaceous clay with lignitic horizons. Dinocyst assemblages in this interval have extremely low diversity and Polysphaeridium zoharyi is still persistently present. In addition, however, Pyxidinopsis sp. is present to common in these marginally marine assemblages. The assemblages in which Pyxidinopsis sp. is most common occur above and below a lignite horizon at $116 \mathrm{ft}(35.4 \mathrm{~m}$; samples CM112, CM102, and CM92), indicating that this species could exploit marginal marine deltaic environments such as interdistributary bays or brackish lagoons.

\section{Atlantic City}

During the Miocene at the Atlantic City site, depositional environments were more proximal and updip than at the Cape May site. Dinocyst assemblages in the 30 analyzed samples reflect this difference: diversity is moderate to low; preservation is fair to good; and in the upper part of the borehole samples lack even organic palynofacies. Despite this, it was possible to delineate a sound dinocyst stratigraphy for much of the Miocene interval (Fig. 4).

The unconformable Oligocene/Miocene boundary in the Atlantic City borehole is at $913 \mathrm{ft}$ (278.3 m; Fig. 4; Miller et al., Chapter 14, this volume). Lean dinocyst assemblages just below the unconformity (samples AT919 and AT916.5; 280.1 and $279.3 \mathrm{~m}$; Table 2) are characterized by Apteodinium spiridoides, Chiropteridium galea, and Homotryblium vallum/plectilum complex. Rare specimens of an unidentified species of Glaphyrocysta in sample AT916 (279.2 m), however, argue against this interval belonging to the upper upper Oligocene to lower Miocene Distatodinium biffii Zone (DN1). This is supported by Sr-isotopic age control, which indicates that this interval is middle upper Oligocene (Fig. 4; Sugarman et al., Chapter 12, this volume; Miller et al., Chapter 14, this volume).

Sample AT898.3 (273.8 m) is from a glauconitic sandy unit between the unconformity at $914 \mathrm{ft}(278.6 \mathrm{~m})$ and another at $881 \mathrm{ft}$ (268.5 m; Fig. 4). Organic matter is rare in the residue and dinocysts are absent. Sr-isotopic age control suggests that this interval is equivalent to Zone DN1 (Fig. 4).

The Sumatradinium soucouyantiae Zone (DN2) is present in the Atlantic City borehole over a 140 -ft-thick $(42.7 \mathrm{~m})$ interval from samples AT879 to AT739.5 (267.9-225.4 m; Fig. 4; Table 2). In the absence of Exochosphaeridium insigne, which is not present in the borehole, the upper boundary of Zone DN2 is delineated by the HO of Cordosphaeridium cantharellus. Even the occurrence of Cordosphaeridium cantharellus is sporadic in these proximal facies (Table 2). Above this level, a single occurrence of rare specimens of Cerebrocysta satchelliae, in sample AT723.9 (220.6 m), indicates that Zone DN2 equivalent strata probably extend to the unconformity at $666 \mathrm{ft}$ (203 m; Fig. 4; de Verteuil and Norris, 1996a). The proximal deltaic environment of the Zone DN2 interval is reflected in the dinocyst assemblages: above $\sim 825 \mathrm{ft}(251.5 \mathrm{~m})$ Lingulodinium machaerophorum, Heteraulacacysta campanula and species in the Paralecaniella-Ascostomocystis group become relatively common, and diversity is low.

A shift to somewhat more open marine dinocyst assemblages occurs abruptly from sample AT655.9 $(199.9 \mathrm{~m})$, right above the unconformity at $666 \mathrm{ft}(203 \mathrm{~m})$, as recorded in increased abundances of Apteodinium spiridoides, Pentadinium laticinctum, Sumatradinium soucouyantiae, and Systematophora placacantha (Table 2). The Couteaudinium aubryae Zone (DN3) is defined from the HO of Exochosphaeridium insigne to the LO of Labyrinthodinium truncatum (de Verteuil and Norris, 1996a). In the Atlantic City borehole, Zone DN3 is delineated between unconformities at 666 and $512 \mathrm{ft}$ (203 and $156.1 \mathrm{~m}$; Fig. 4). Sr-isotopic stratigraphy supports placing the boundary between Zones DN2 and DN3 at $666 \mathrm{ft}$ (203 m; Fig 4; Miller et al., Chapter 14, this volume). The upper boundary is delineated based on the LO of Labyrinthodinium truncatum modicum in sample AT503.2 (153.4 m), just above the unconformity at $512 \mathrm{ft}(156.1 \mathrm{~m}$; Fig. 4; Table 2).

In sample AT503.2 (153.4 m), the presence of Labyrinthodinium truncatum modicum without Labyrinthodinium truncatum truncatum suggests that it belongs to Zone DN4 (de Verteuil and Norris, 1996a). The HO of Distatodinium paradoxum, which defines the upper boundary of Zone DN4, however, is below this level in sample AT526 (Table 2). The dinocyst assemblage and palynofacies from sample AT503.2 $(160.3 \mathrm{~m})$ are indicative of strong deltaic/nonmarine influence, which may account for the absence of Distatodinium paradoxum. Based on this, and strong support for a lower middle Miocene position from the Sr-isotopic stratigraphy, the interval between 512 and $470 \mathrm{ft}(156.1$ and $143.3 \mathrm{~m})$ is here included in Zone DN4 (Fig. 4).

Dinocyst assemblages and palynofacies above the $470 \mathrm{ft}(143.3$ m) unconformity, such as from sample AT460 (140.2 m), are more diverse and indicative of open marine conditions. The occurrence of Habibacysta tectata, Trinovantedinium harpagonium, and Systematophora placacantha confirm the presence of the Batiacasphaera sphaerica Zone (DN5; Table 2). Furthermore, the occurrence of Habibacysta tectata indicates the presence of the upper part of Zone DN5 (de Verteuil and Norris, 1996a), in agreement with the Sr-isotopic stratigraphy (Fig. 4). The HO of Systematophora placacantha in 
Table 1. Occurrence data for selected dinoflagellate taxa from the Cape May borehole.

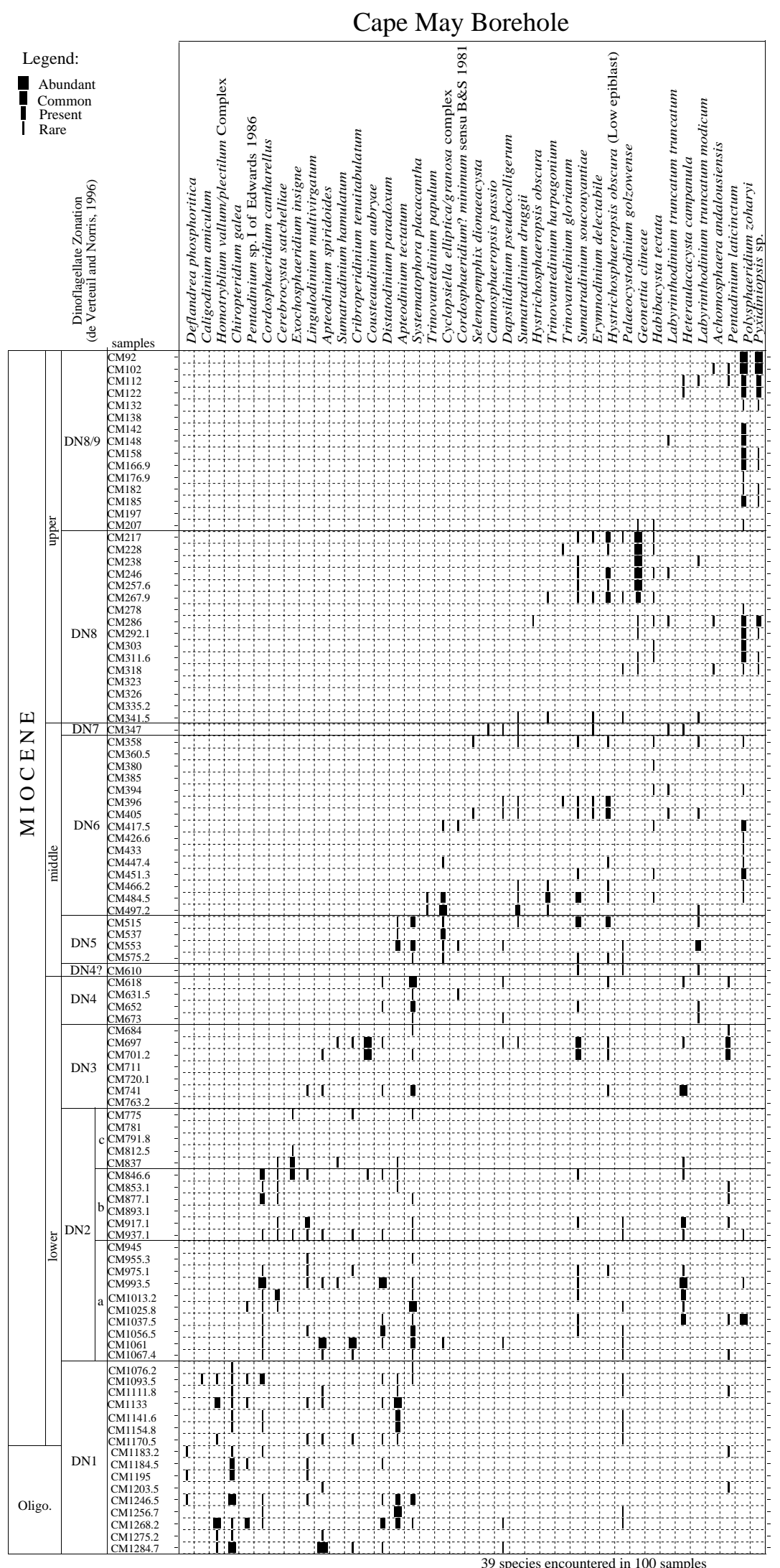

Notes: Sample numbers reflect the sample depths in feet in the borehole. The qualitative terms rare, present, common, and abundant are defined in the methods section. Taxonomy follows de Verteuil and Norris (1996a, 1996b, 1996c). 
sample AT394.9 (120.4 m) delineates the upper limit of Zone DN5 in the Atlantic City borehole (Table 2), although the zone probably extends as high as the unconformity at $370 \mathrm{ft}$ (112.8 m; Fig. 4). Above this level, six samples between 292 and $121 \mathrm{ft}(89$ and $36.9 \mathrm{~m}$ ) yielded no dinocysts or palynofacies (Table 2), indicating extreme oxidation of the original organic content of these sands.

A single sample from the gray clay bed just above the unconformity at $53 \mathrm{ft}(16.2 \mathrm{~m}$; sample AT46.9; $14.3 \mathrm{~m})$ yielded palynofacies strongly dominated by terrestrial phytoclasts and plant membranes with only rare dinocysts, indicating a nearshore, marginal marine environment. The low diversity dinocyst assemblage is dominated by Polysphaeridium zoharyi, suggesting a (sub)tropical climate. Filisphaera microornata is the only stratigraphically useful dinocyst in sample AT46.9; it indicates a Zone DN9 position or above (de Verteuil and Norris, 1996a).

\section{Miocene Sequence Correlations}

Prior to Leg 150X drilling at the Island Beach, Atlantic City, and Cape May sites, Sugarman et al. (1993) delineated three lower and middle Miocene sequences in the subsurface Kirkwood Formation of New Jersey, which they called Kirkwood 1, 2, and 3. The ACGS-4 and Belleplain State Forest boreholes, and the Wildwood 198A well, provided primary reference sections for their sequences (Fig. 1). De Verteuil and Norris (1996a) showed that in the ACGS-4 borehole the Kirkwood 1 sequence belongs to Zone DN2 and the Kirkwood 2 sequence belongs to Zone DN3. Cross-correlation of diatom and dinocyst stratigraphy in Maryland reference outcrops (East Coast Diatom Zonation or ECDZ of Andrews, 1988; de Verteuil and Norris, 1996a) suggests that the Kirkwood 3 sequence in the Belleplain borehole belongs to lower Zone DN6 and possibly upper Zone DN5 (vis. lower ECDZ6 and possibly ECDZ5; Sugarman et al., 1993). A sample from $41.7 \mathrm{ft}(12.7 \mathrm{~m})$ in the Belleplain borehole, above the Kirkwood 3 sequence, belongs to dinocyst Zone DN6 (de Verteuil and Edwards, 1992), supporting this suggestion.

Stratigraphic data from Leg $150 \mathrm{X}$ boreholes resulted in refinement of the Kirkwood sequence framework and terminology (Kw0, $\mathrm{Kw} 1 \mathrm{a}, \mathrm{Kw} 1 \mathrm{~b}, \mathrm{Kw} 1 \mathrm{c}, \mathrm{Kw} 2 \mathrm{a}, \mathrm{Kw} 2 \mathrm{~b}, \mathrm{Kw} 3$ and Kirkwood-Cohansey; Miller and Sugarman, 1995; Miller, et al., 1996a; Miller et al., Chapter 14, this volume). New dinocyst stratigraphic correlations in the present paper have produced further refinements (Kw2a', Kw2a", $\mathrm{Kw} 3 \mathrm{a}, \mathrm{Kw} 3 \mathrm{~b}$ ). In addition, the name Kirkwood-Cohansey sequence is cumbersome, and dinocyst stratigraphy indicates that this sequence at Cape May (Zone DN6) is correlative with Cohansey Sand facies updip at Belleplain State Forest (Fig. 1). Therefore, since the Kirkwood-Cohansey sequence of Miller and co-workers probably represents the lowest sequence of the Cohansey Sand, I use instead the name Cohansey 1 sequence $(\mathrm{Ch} 1)$.

The present paper provides the first robust evidence for upper Miocene sequences in New Jersey overlying the middle Miocene Cohansey Sand (vis. Zone DN8 and DN8/9 units in Cape May borehole). Herein, I informally refer to these upper Miocene sequences as the upper Cohansey Sand and introduce terminology for individual sequences (Ch2-Ch6; Fig. 4). Lithofacies in these upper Miocene units comprise mixed sands, silts and clays, deposited in marginal marine and nearshore deltaic/estuarine environments (Miller et al., Chapter 14, this volume). They are so similar to the underlying Cohansey Sand facies that it is presently uncertain whether they can be distinguished (and mapped) on the basis of lithology alone.

\section{Kirkwood Sequences}

\section{Kw0 Sequence}

The Kw0 sequence at Cape May extends from 1180 to $1062 \mathrm{ft}$ (359.8-323.8 m; Miller et al., Chapter 14, this volume) and belongs to the upper part of Zone DN1 above the HO of Deflandrea phosphoritica (Fig 4; Table 1). Miller et al. (Chapter 14, this volume) de- lineated the Kw0 sequence at Atlantic City from 913 to $888 \mathrm{ft}$ (278.4-270.7 m) on the basis of lithostratigraphy and Sr-isotopic stratigraphy. A single palynological sample from within this interval (sample AT898.3) is barren but the interval is inferred to belong to Zone DN1 (Fig. 4).

\section{Kw1a Sequence}

Dinocyst stratigraphy indicates that the Kwla sequence at Cape May extends from 1062 to $942 \mathrm{ft}(323.8-287.1 \mathrm{~m})$ corresponding to the lower part of Zone DN2 below the LO of Exochosphaeridium insigne (Subzone DN2a; Fig. 2), in agreement with the lithostratigraphic, biofacies and sequence analysis of Miller et al. (Chapter 14, this volume). At Atlantic City the Kw1a sequence delineated by Miller et al. (Chapter 14, this volume; 888-741 ft [270.7-225.9 m]) also belongs to Subzone DN2a (Fig. 4; Table 2). In the lower part of the Kirkwood 1 sequence in the ACGS-4 borehole Exochosphaeridium insigne is absent from Zone DN2 (unnamed allounit; de Verteuil and Norris, 1996a). This indicates that the unnamed allounit at ACGS-4 is the $\mathrm{Kw} 1 \mathrm{a}$ sequence, in agreement with $\mathrm{Sr}$-isotopic age estimates (Sugarman et al., 1993). Thus, in the New Jersey coastal plain, the Kwla sequence corresponds to the interval between the HO of Chiropteridium galea and the LO of Exochosphaeridium insigne.

\section{Kw1b Sequence}

The Kw1b sequence at Cape May extends from 942 to $850 \mathrm{ft}$ (287.1-259.1 m; Miller et al., Chapter 14, this volume). This corresponds to the interval from the LO of Exochosphaeridium insigne $(937.1 \mathrm{ft}[285.6 \mathrm{~m}])$ to the $\mathrm{HO}$ of Cordosphaeridium cantharellus $(846.6 \mathrm{ft},[258 \mathrm{~m}])$, that is, to Subzone DN2b. Specimens of Cordosphaeridium cantharellus in sample CM846.6 have shorter processes than is usual and may represent morphological instability at the top of the species' range. Alternatively, its HO just above the KW1b upper boundary may be due to reworking, or else may indicate that the Kw1b sequence includes a clay-rich confining unit up to about $830 \mathrm{ft}(253 \mathrm{~m})$. In the absence of Exochosphaeridium insigne in the Atlantic City borehole, this concurrent range interval cannot be delineated there. Miller et al. (Chapter 14, this volume) included the interval from 741 to $666 \mathrm{ft}(225.9-203 \mathrm{~m})$ in the Kw1b sequence at Atlantic City (Fig. 4). The absence of Exochosphaeridium insigne in this interval may be explained by the presence of proximal, sandy facies. Alternatively, the interval in question may be age equivalent to the upper part of the Kwla sequence at Cape May, a possibility for which the Sr-isotopic data provide equivocal support (Sugarman et al., Chapter 12, this volume; Fig. 4). Exochosphaeridium insigne is also absent in the ACGS-4 borehole although Sr-isotopic dates from the upper $100 \mathrm{ft}$ of the lower Kirkwood sequence of Sugarman et al. (1993), indicate age equivalence with the Kw1b and upper Kw1a sequences at Cape May. In summary, in neritic or deeper environments, the range concurrence of Exochosphaeridium insigne and Cordosphaeridium cantharellus is within the $\mathrm{Kw} 1 \mathrm{~b}$ sequence.

\section{Kw1c Sequence}

Dinocyst stratigraphy in the Cape May borehole delineates an important break at $764 \mathrm{ft}(232.9 \mathrm{~m})$, between samples CM775 and CM763.2 (236.2 and $232.6 \mathrm{~m}$ ), corresponding to the boundary between Zones DN2 and DN3 (Fig. 4; Table 1). Miller et al. (Chapter 14 , this volume) included the interval from 850 to $710 \mathrm{ft}$ (259.1$216.4 \mathrm{~m}$ ) in the Kw1c sequence at Cape May and interpreted the indurated horizon at $764 \mathrm{ft}(232.9 \mathrm{~m})$ as an intrasequence flooding surface. Based on regional stratigraphic relationships at the Zone DN2/ DN3 boundary (de Verteuil and Norris, 1996a, unpubl. data), I interpret the same horizon as the upper boundary of the Kw1c sequence (Fig. 4). Thus, the Kw1c sequence was deposited during Subzone DN2c, between the $\mathrm{HO}$ of Cordosphaeridium cantharellus and the 
Table 2. Occurrence data for selected dinoflagellate taxa from the Atlantic City borehole.

\section{Atlantic City Borehole}
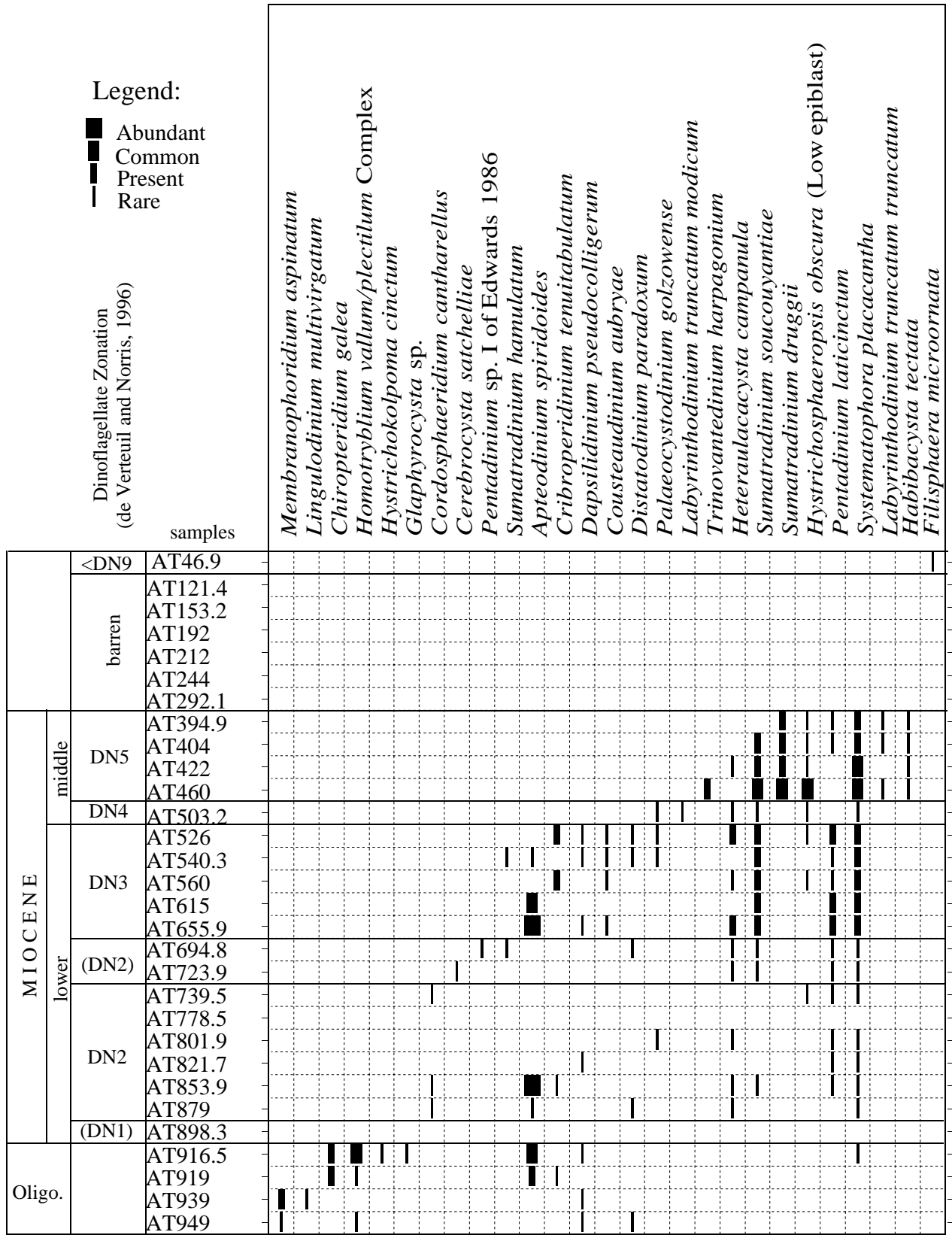

27 species encountered in 30 samples

Notes: Sample numbers reflect the sample depths in feet in the borehole. The qualitative terms rare, present, common, and abundant are defined in the methods section. Taxonomy follows de Verteuil and Norris (1996a, 1996b, 1996c).

HO of Exochosphaeridium insigne. Limited Sr-isotopic data give an age close to 19 m.y. for the Kwlc sequence as understood herein (Sugarman et al., Chapter 12, this volume). Dinocyst and Sr-isotopic stratigraphy both indicate that the Kw1c sequence is not present in the Atlantic City borehole (Fig. 4).

\section{Kw2a Sequence}

The dinocyst stratigraphic results from this study indicate a need to revise the Kw2 sequence terminology of Miller et al. (Chapter 14, this volume). In the Cape May borehole, the interval from 764 to 680 $\mathrm{ft}$ (232.9-207.3 m) belongs to Zone DN3 (see above). The indurated sand and overlying shell bed at $680 \mathrm{ft}(207.3 \mathrm{~m})$, overlying Zone DN3, can be readily interpreted as a sequence boundary as opposed to the maximum flooding surface favored by Miller et al. (Chapter 14 , this volume). These authors interpret the underlying facies succession, from $710 \mathrm{ft}(216.4 \mathrm{~m})$, as a deepening-upward transgressive systems tract. Palynofacies in samples CM701.2 and CM697 (213.7 and $212.4 \mathrm{~m}$ ) are dominated by terrestrial macrophyte phytoclasts, however, and indicate shallowing-upward deltaic influence. Thus, the unconformity at $680 \mathrm{ft}$ marks the upper boundary of the Kw2a sequence as understood herein, with the lower boundary placed at 764 
$\mathrm{ft}$ (232.9 m; Fig. 4). Within this interval there is a lithologic and Srisotopic break at $710 \mathrm{ft}(216.4 \mathrm{~m})$, which Miller et al. (Chapter 14, this volume) interpret as the lower boundary of their Kw2a sequence and which is here viewed as separating a lower $\mathrm{Kw} 2 \mathrm{a}^{\prime}$ sequence from an upper Kw2a" sequence (Fig. 4). The Kw2a' sequence between 764 and $710 \mathrm{ft}$ is characterized by poor recovery (Miller, et al., 1996a), but samples CM741 and CM721.1 (225.9 and 219.8 m) are dominated by a marine amorphous organic matter with low dinocyst abundance and diversity and very little pollen. Given the general depositional setting, this palynofacies indicates shallowing upwards marine deposition without deltaic influence. Although in general regressive relationship to one another, therefore, the Kw2a' and Kw2a" units still appear to be genetically distinct and, on the basis of Sr-isotopic stratigraphy, are separated by an approximately 1 m.y. hiatus (Fig. 4). It is worth noting here that the same allostratigraphic succession within Zone DN3 is present in the Salisbury Embayment (de Verteuil and Norris, 1996a; see below).

In the Atlantic City borehole Zone DN3 is present from 666 to 512 ft (203-156.1 m; Fig. 4). The monotony of the gamma log and the Srisotopic ages within this interval suggest that only the younger, Kw2a" sequence is present (Fig. 4).

\section{Kw2b Sequence}

Miller et al. (Chapter 14, this volume) placed the upper boundary or the Kw2a sequence at $615 \mathrm{ft}(187.5 \mathrm{~m})$ in the Cape May borehole. Dinocyst stratigraphy in this study indicates that the sequence boundary occurs at $680 \mathrm{ft}(207.3 \mathrm{~m})$, coincident with Zone DN3/DN4 boundary. The lower boundary of the Kw $2 \mathrm{~b}$ sequence is therefore extended down to this level (Fig. 4). Recovery at Cape May between 615 and $576 \mathrm{ft}$ was poor (187.5 and $175.6 \mathrm{~m}$; Kw2b sequence of Miller et al., Chapter 14, this volume). Only one palynology sample was available from this interval (sample CM610, $185.9 \mathrm{~m}$; Zone DN4/5 see above) but $\mathrm{Sr}$-isotopic dates suggest age equivalence with upper Zone DN4 using the zonation age calibration of de Verteuil and Norris (1996a). The sequence stratigraphic context of the unconformity at $615 \mathrm{ft}$ is uncertain: it may represent either a distinct sequence boundary of regional significance or a local intrasequence erosional surface. At Atlantic City, the Kw2b sequence (512-540 ft [156.1-143.3 m]) was provisionally included in Zone DN4 based on a single sample and the Sr-isotopic data (sample AT503.2, see above; Fig. 4). At both sites, therefore, the Kw2b sequence belongs to Zone DN4.

\section{Kw2c Sequence}

The Kw2c sequence was only penetrated in the Cape May borehole (576-503 ft [175.6-153.3 m]; Miller et al., Chapter 14, this volume). It belongs there to the lower part of Zone DN5 (see above) and has a Sr-isotopic-based age of about 14.5 m.y. (Fig. 4). The absence of lower Zone DN5 strata in the Atlantic City borehole supports the view that the $\mathrm{Kw} 2 \mathrm{c}$ sequence is not represented there.

\section{Kw3a and $3 b$ Sequences}

Miller et al. (Chapter 14, this volume and references therein) recognized a single middle Miocene Kw3 sequence in the subsurface of the New Jersey coastal plain. Dinocyst stratigraphy, however, shows unambiguously that, at Cape May and Atlantic City, the Kw3 sequence of those authors comprises an older sequence (Kw3a) and a second, younger sequence (Kw3b; Fig. 4). The lower, Kw3a sequence is only represented in the Atlantic City borehole (470-370 ft [143.3-112.8 m]) and belongs to the upper part of Zone DN5, which includes the species Habibacysta tectata (see above; Fig. 4). Qualitative palynofacies from samples AT460 through AT394.9 within the $\mathrm{Kw} 3 \mathrm{a}$ sequence, indicate progressive shallowing upward and increased terrestrial influence (macrophyte phytoclasts) from an initial open marine middle neritic environment (common marine amor- phous organic matter, relatively diverse dinocysts, low diversity pollen). This palynofacies succession indicates the presence of a full transgressive/regressive cycle as suggested by Miller et al. (Chapter 14 , this volume).

The upper, Kw3b sequence, on the other hand, is present only in the Cape May borehole (503-432 ft [153.3-131.7 m]) and belongs to Zone DN6 (Fig. 4). Open marine dinocyst assemblages in the lower part of the Kw3b sequence exclude the possibility that the absence of Systematophora placacantha in these assemblages results from ecological exclusion, and so confirm the DN6 zonal affinity. Qualitative palynofacies (samples CM497.2 through CM433) show the same transgressive/regressive trends within the $\mathrm{Kw} 3 \mathrm{~b}$ sequence as observed in the Kw3a sequence, but with more oxidation in the upper, sandy, progradational highstand facies.

\section{Cohansey Sequences}

In the Cape May borehole, the interval from 432 to $90 \mathrm{ft}$ (153.3$27.4 \mathrm{~m}$ ) contains six unconformity bound cycles that are recognizable with the help of dinocyst stratigraphy, abundance patterns, and palynofacies. An approximately equivalent but more sand-prone succession in the Atlantic City borehole, containing perhaps four cycles recognizable on the basis of lithostratigraphy and wireline log stratigraphy only, is present from 370 to $53 \mathrm{ft}(112.8-16.2 \mathrm{~m}$; Fig. 4). Six palynology samples from this interval are barren and in the absence of either foraminiferal or Sr-isotopic data precise correlation of the two boreholes is not attempted. Thus, the informal Cohansey sequences are described from the Cape May site only.

\section{Ch1 Sequence (=Kw-Cohansey)}

At Cape May the Ch1 sequence is represented from 421 to $357 \mathrm{ft}$ (128.3-108.8 m) and belongs to Zone DN6 (Fig. 4). The lithologic and benthic foraminiferal biofacies succession was described by Miller et al. (Chapter 14, this volume; as Kw-Cohansey sequence); the gamma $\log$ also shows the first fining and then coarseningupward trace characteristic of New Jersey Miocene transgressive/ regressive cycles discussed by Miller et al. (Chapter 14, this volume). Dinocysts are rare to present and diversity is low within this sequence, and palynofacies are dominated by terrestrial kerogen that shows indications of oxidation.

\section{Ch2 Sequence}

The $\mathrm{Ch} 2$ sequence is a thin, marginal marine unit present from 357 to $322 \mathrm{ft}$ (108.8-98.1 m; Fig. 4). At the base, it grades from a laminated clay and silty fine micaceous sand, with carbonaceous horizons (357-342 ft [108.8-104.2 m]), to a more sandy clay with lignitic layers (Miller, et al., 1996a). sample CM407 from near the base contains a well-preserved terrestrial macrophyte dominated palynofacies and protoperidinioid dominated dinocyst assemblages, both indicative of an inner neritic environment. The presence of Cannosphaeropsis passio in this sample indicates that at least the lower part of the Ch2 sequence belongs to Zone DN7 (Table 1). Dinocysts are rare to absent in the upper part of the sequence due to extremely marginal marine conditions.

\section{Ch3 Sequence}

The Ch3 sequence is a mainly medium to coarse sand with a uniform gamma-log profile, and is present from 322 to $274 \mathrm{ft}(98.1-83.5$ m; Fig. 4). The presence of Achomosphaera andalousiensis near the base of the Ch3 sequence indicates that it belongs to Zone DN8 (see above). Kerogen preservation is poor in the $\mathrm{Ch} 3$ sands, but the interval is notable for a minor acme of Polysphaeridium zoharyi, a dinocyst that is absent or rare lower in the Miocene section (Table 3). Polysphaeridium zoharyi is an opportunistic extant species and clas- 
sic indicator of tropical to subtropical embayments and lagoons (Wall et al., 1977; de Verteuil and Norris, 1996c); its presence in the Ch3 sequence is consistent with its occurrence in other Zone DN7 and lower Zone DN8 assemblages from offshore New Jersey (de Verteuil, 1996).

\section{Ch4 Sequence}

The base of the Ch4 sequence is marked by a pebble and coarse sand bed at $274 \mathrm{ft}(83.5 \mathrm{~m})$, which grades rapidly into a uniform, micaceous, fine to very fine clay-rich sand (Miller, et al., 1996a). Slightly increased gamma values with respect to the underlying $\mathrm{Ch} 3$ sequence reflect the increased clay content (Fig. 4). The upper boundary of the $\mathrm{Ch} 4$ sequence occurs at $\sim 210 \mathrm{ft}(64 \mathrm{~m})$ and is marked by a decrease in gamma values and corresponding decrease of the clay fraction (Fig. 4). The Ch4 sequence clearly belongs to Zone DN8 (see above) but unlike the Ch3 sequence, it lacks Polysphaeridium zoharyi and is characterized by common Geonettia clineae (Table 1). De Verteuil and Norris (1996c) inferred a mesotrophic, warm-temperate, opportunistic ecology in low sedimentation, neritic environments for Geonettia clineae.

\section{Ch5 Sequence}

The Ch5 sequence (210-140 ft [64-42.7 m]) is a rather uniform silty medium sand that fines upward into an organic-rich medium to fine sand with carbonaceous and clayey horizons. The gamma-log values are uniformly low and decrease slightly upsection, perhaps reflecting the increased carbonaceous content (Fig. 4). Qualitative palynofacies indicate initial middle to inner neritic environments (210$200 \mathrm{ft}$ [64-61 m]; mixed terrigenous and marine kerogen with common dinocysts), followed by transgression (200-190 ft [61-58 m]; marine amorphous kerogen), followed by increasing highstand progradation/regression (190-140 ft [58-42.7 m]; dark recycled gelified kerogen grading into more fresh but degraded penecontemporaneous structured terrestrial phytoclasts; upward decrease in dinocyst abundance and diversity). The Ch5 sequence belongs to undifferentiated Zone DN8/9 as explained above. Geonettia clineae, common in the underlying sequence, is absent from the Ch5 sequence. Instead Polysphaeridium zoharyi reappears in the record at Cape May (Table 1), perhaps indicating a more proximal, less saline environment rather than any marked warming.

\section{Ch6 Sequence}

The Ch6 sequence (140-90 ft [58-27.4 m]) is the uppermost Miocene sequence represented at Cape May (Fig. 4). Radiocarbon ages indicate that overlying sediments are upper Quaternary (Miller, et al., 1996a). The presence of Labyrinthodinium truncatum truncatum in sample CM112 (34.1 m) indicates that the Ch6 sequence is not younger than middle late Miocene (Zone DN9). The base of the Ch6 sequence is marked by a pebble and coarse sand interval (140-135 ft [58-41.1 m]) that grades rapidly into an irregularly laminated, micaceous silty clay with some shells and carbonaceous horizons (Miller, et al., 1996a). The gamma-log values clearly show the increased clay content of the $\mathrm{Ch} 6$ sequence and palynofacies from this interval are thoroughly dominated by well-preserved structured macrophyte phytoclasts (i.e., land plant tissues). This and the low diversity dinocyst assemblages dominated by Polysphaeridium zoharyi, Spiniferites spp. and undescribed Pyxidinopsis sp., confirm a marginal marine estuarine-like environment.

\section{CHRONOLOGY AND ACCUMULATION RATES}

In this section I integrate the dinocyst stratigraphy, calibrated to the BKSA95 time scale by de Verteuil and Norris (1996a), with Sr- isotopic stratigraphy from Miller et al. (Chapter 14, this volume), and Sugarman et al. (Chapter 12, this volume), to develop a chronology for Miocene deposition in New Jersey (Figs. 2, 3). There is excellent agreement between the dinocyst and $\mathrm{Sr}$-isotopic ages for the lower and lower middle Miocene (Zone DN2-DN5), particularly for the Cape May borehole, resulting in a similar chronology as that presented by Miller et al. (Chapter 14, this volume) for these sites. Older age calibrations for Zones DN6 and DN7 (de Verteuil and Norris, 1996a), with respect to younger $\mathrm{Sr}$-isotopic ages produced from the Kw3b and Ch1 sequences (Sugarman et al., Chapter 12, this volume), result in some discrepancy for the middle Miocene between the two independent dating methods. Sr-isotopic ages are not available for the upper Miocene.

The error associated with the Sr-isotopic dates ranges from \pm 0.6 m.y. to \pm 1.2 m.y. but is \pm 0.6 m.y. for most of the lower and lower middle Miocene (Sugarman et al., Chapter 12, this volume). The errors associated with age estimates of regional $\mathrm{LO}$ and $\mathrm{HO}$ dinocyst events range from \pm 0.5 m.y. to \pm 1.5 m.y. (de Verteuil and Norris, 1996a); of course most events in the present material will be somewhat premature (HOs) or delayed (LOs) due to proximal facies and erosion; indeed some are markedly so (e.g., HO of Distatodinium paradoxum; Figs. 2, 3). Thus, although the position and duration of the shorter hiatuses between individual sequences is not precise (gray bars in Figs. 2 and 3), they are included in the models because some time is unrepresented by rock at each erosional break. Similarly, the average accumulation rates for individual sequences or stratigraphic intervals based on these models (uncorrected for compaction and ignoring erosion), must be viewed as crude estimates of overall sediment accumulation/preservation rather than true sedimentation (process) rates. They are most useful for comparing depocenter movement, sediment bypass and other basin-scale phenomena on a regional basis.

In the Cape May borehole, the base of the Kw0 sequence is of earliest Miocene age ( 23.6 m.y.) and Sr-isotopes from the underlying upper Oligocene sequence suggest that the Oligocene/Miocene hiatus represents less than 1.0 m.y. (Fig. 2). Up to 2.0 m.y. may be unrepresented by record at the Atlantic City site, although a much shorter hiatus can also be inferred from the available Sr-isotopic ages (Fig. 3). The age of the Kw0 sequence based on both sites is from 23.6 to 22.2 m.y. (2.2 m.y.), indicating the presence of a nearly complete record of the basal Miocene transgression in New Jersey. Kw0 accumulation at Cape May averaged $\sim 26 \mathrm{~m} / \mathrm{Ma}$.

The $\mathrm{Kw} 1 \mathrm{a}, \mathrm{Kw} 1 \mathrm{~b}$, and $\mathrm{Kw} 1 \mathrm{c}$ sequences were all deposited over a $\sim 1.8$ m.y. interval between $\sim 19$ m.y. and 20.8 m.y. (Figs. 2, 3). The agreement in ages between the models for the two sites is remarkable, particularly the coincidence of the hiatus where the Kw1c sequence is not preserved at Atlantic City. The combined accumulation rate for all three sequences at Cape May is $\sim 50 \mathrm{~m} / \mathrm{Ma}$; at Atlantic City the $\mathrm{Kw} 1 \mathrm{a}$ and Kw1b alone have a comparable rate of $68 \mathrm{~m} / \mathrm{Ma}$. As shown, the LO and $\mathrm{HO}$ of Exochosphaeridium insigne and the $\mathrm{HO}$ of Cordosphaeridium cantharellus each correlate with the position of a Kw1 sequence boundary (Table 1; Fig. 2). Their positions along the line of correlation in the Cape May model (Fig. 2) strongly suggest that at this site the overall Kw1 record is almost uninterrupted (short duration hiatuses). De Verteuil and Norris (1996a) estimated the HO of Exochosphaeridium insigne datum at 20.5 m.y. and using their estimate it plots above/left of the line of correlation through the Cape May strontium data (Fig. 2). The HO of Exochosphaeridium insigne is therefore probably better estimated as 20.0 m.y.

In addition to the Kw1c sequence, Sr-isotopic ages suggest that the Kw2 $\mathrm{a}^{\prime}$ sequence is also missing from the Atlantic City record; this results in a $\sim 2$ m.y. hiatus (17.8-19.8 m.y.; Fig. 3). At both sites the upper age of the Kw2a" sequence is quite well constrained by Srisotopes and the LO of Labyrinthodinium truncatum at $\sim 16.8$ m.y. The HO of Exochosphaeridium insigne at $\sim 19$ m.y. provides a lower limit for the onset of Kw2a' deposition, although the actual timing is likely slightly younger (Fig. 2). Using both age/depth models, I esti- 
mate Kw2a' deposition from $~ 18.8-18.0 \mathrm{Ma}$, and Kw2a" deposition from $~ 17.9-16.8 \mathrm{Ma}$, with less than $0.2 \mathrm{~m}$.y. of unrepresented time between the two sequences (Figs. 2, 3). These estimates result in average accumulation rates of $21 \mathrm{~m} / \mathrm{Ma}$ for the $\mathrm{Kw} 2 \mathrm{a}^{\prime}$ sequence and 43 $\mathrm{m} / \mathrm{Ma}$ for the Kw2a" sequence at Atlantic City.

The Kw2b sequence dates from the lower part of Zone DN4 at Cape May ( 16.5 m.y.) and Sr-isotopic ages for the upper part of this sequence at both sites cluster around 15.5-16.0 Ma, or wholly within Zone DN4. The upper boundary of Zone DN4 is defined by the HO of Distatodinium paradoxum, but this event is premature in both models (falls below the line of correlation), suggesting taphonomic and/or paleoecological exclusion.

The Kw2c sequence is present only at Cape May and the Kw3a sequence only at Atlantic City (Fig. 4). There is excellent agreement on the reciprocal timing of preserved record and hiatuses between the two sites within the Zone DN5 interval. The Kw2c sequence ( 15.014.2 m.y.) is constrained by Sr-isotopes and the LO of Habibacysta tectata event (Fig. 2), while at the Atlantic City site, a hiatus is present from $\sim 15.5$ to 14.0 m.y. and no lower Zone DN5 strata are present (Fig. 3). A hiatus between 14.2 m.y. and 13.2, based on the HO of Systematophora placacantha, corresponds to the missing Kw3a sequence at Cape May (Fig. 2). The same upper Zone DN5 interval is represented at Atlantic City by the Kw3a sequence (14.013.2 m.y.), and is tightly constrained by the LO of Habibacysta tectata, the HO of Systematophora placacantha, and four Sr-isotopic ages (Fig. 3).

Age control for the remaining middle and upper Miocene sequences comes solely from the Cape May section and in the present model is restricted to dinocyst datum calibrations from de Verteuil and Norris (1996a). Providing that the LO of Cannosphaeropsis passio at Cape May is not delayed, the $\mathrm{Kw} 3 \mathrm{~b}$ and $\mathrm{Ch} 1$ sequences both belong to Zone DN6 (Fig. 2). Alternatively, the Ch1 sequence may be Zone DN7 equivalent, as suggested by the presence of Erymnodinium delectabile and Trinovantedinium glorianum (Table 1). For the present, however, I favor a Zone DN6 interpretation for the Ch1 sequence because palynofacies within it (e.g., samples CM405 and CM396) contain mixed marine amorphous, terrestrial structured, and relatively diverse dinocyst components, and so Cannosphaeropsis passio should not be ecologically excluded. This interpretation results in both sequences being deposited over less than 0.5 m.y. (13.212.8 m.y.), with an unresolved hiatus between them (Fig. 2). The average accumulation rate for the combined $\mathrm{Kw} 3 \mathrm{~b} / \mathrm{Ch} 1$ interval at Cape May is $\sim 110 \mathrm{~m} / \mathrm{Ma}$, more than twice that of any of the other Miocene sequences at either site.

Eight $\mathrm{Sr}$-isotopic ages from the $\mathrm{Ch} 1$ sequence cluster around 11.9 m.y. (Fig. 2) and so fall below the dinocyst-based line of correlation in the present Cape May age model. The rate of increase of oceanic ${ }^{87} \mathrm{Sr} /{ }^{86} \mathrm{Sr}$ decreased in the middle Miocene resulting in less precise age estimates that are represented by error bars of \pm 1.2 m.y. in Figure 2 (Miller et al., 1991; Oslick et al. 1994). The consistency of the Srisotopic data, however, indicates that the offset between the $\mathrm{Sr}$ and dinocyst stratigraphies results from calibration differences. These may arise in small part from minor differences between the CK92 (Cande and Kent, 1992; used by Oslick et al., 1994), and the BKSA95 (used by de Verteuil and Norris, 1996a) time scales, but are principally due to unresolved complexities in upper middle Miocene global magnetobiostratigraphy and geochronology (e.g., Aubry, 1993; Berggren 1993; Miller et al., 1994b; Berggren et al., 1995).

The Ch3 and Ch4 sequences belong to Zone DN8 and are constrained by the LO of Achomosphaera andalousiensis ( 10.5 m.y.) and the HOs of Palaeocystodinium golzowense and Sumatradinium soucouyantiae (both $~ 8.6$ m.y.). Although the $\mathrm{Ch} 5$ and Ch6 sequences may also belong to Zone DN8, as discussed above, the present age model conservatively assumes that they belong to Zone DN9. There is no control on the duration of hiatuses in the Ch3-Ch6 interval (322-90 $\mathrm{ft}$ [98.1-27.4 m]) and minimal missing record is assumed
(Fig. 2). The HO of Labyrinthodinium truncatum ( 7.4 m.y.) provides the upper control point and is thought to be slightly premature. Using this age model, average accumulation rates within the $\mathrm{Ch} 3$ to Ch6 interval were about $25 \mathrm{~m} / \mathrm{Ma}$.

\section{SALISBURY EMBAYMENT CORRELATIONS}

De Verteuil and Norris (1996a) defined 12 informal allostratigraphic units from outcrops in Maryland and Virginia and related them to dinocyst stratigraphy in the reference sections. They further used dinocyst stratigraphy to extend allostratigraphic correlations into the subsurface and recognized 15 Miocene third-order sequences in the Salisbury Embayment. With the present study it is possible for the first time, via dinocyst stratigraphy, to establish detailed correlations between these Miocene stratigraphic sequences in Maryland and Virginia and those in New Jersey (Fig. 5). This section compares these two records (i.e., mainly deltaic in New Jersey and mainly shallow marine embayment in Maryland/Virginia), and synthesizes a composite of Miocene sequences for the middle Atlantic Coastal Plain. Thus, the present study refines and expands upon the tentative strontium-based sequence correlations of Miller and Sugarman (1995). Salisbury Embayment localities and stratigraphy referred to below are discussed in detail in de Verteuil and Norris (1996a), and the localities are illustrated in Figure 1.

No lowest Miocene Zone DN1 strata have yet been reported from Maryland, Virginia, or Delaware, so there are no confirmed Kw0 sequence equivalents there. The SE1 allounit is 3.5-4 m thick at its reference section at Popes Creek (Fig. 1). This interval was incompletely sampled by de Verteuil and Norris (1996a, fig. 8) and apparently belongs to Zone DN2. Cordosphaeridium cantharellus and Exochosphaeridium insigne are present in the middle of the interval, and Exochosphaeridium insigne alone is present at the top. This suggests that both Subzone DN2b and Subzone DN2c, equivalent to the Kw1b and Kw1c sequences, are present at Popes Creek. What is not known is whether Subzone DN2a, equivalent to the Kw1a sequence, is present at the SE1 allounit reference section.

The Je32-04 borehole in Delaware is located updip from the Cape May site and contains an excellent Zone DN2 interval (Fig. 1). The $\mathrm{LO}$ of Exochosphaeridium insigne and $\mathrm{HO}$ of Cordosphaeridium cantharellus datums are clearly delineated in the Je32-04 borehole (de Verteuil and Norris, 1996a, fig. 14, table 6). Using lithostratigraphy and a clear offset in the gamma log at $236 \mathrm{ft}(72 \mathrm{~m})$ we delineated a lower, unnamed allounit, within Zone DN2 but below the SE1 allounit. The upper boundary of this unnamed allounit coincides with the LO of Exochosphaeridium insigne in the Je32-04 borehole, confirming its equivalence to the Kwla sequence at Cape May. Reexamination of the dinocyst data shows that the HO of Cordosphaeridium cantharellus event in the Je32-04 borehole coincides with a positive increase in gamma values at $208 \mathrm{ft}(63.4 \mathrm{~m})$. This increase is now interpreted as an unconformable lithic change equivalent to the $\mathrm{Kw} 1 \mathrm{~b} / \mathrm{Kw} 1 \mathrm{c}$ contact at Cape May.

From the above, it is clear that the SE1 allounit is equivalent to at least the Kw1a and Kw1b sequences in New Jersey. It also seems likely that Subzone DN2a, Kw1a-equivalent strata will be found in the Virginia/Maryland subsurface. For consistency in nomenclature, therefore, the SE1 allounit is herein recognized as comprising the SE1a, SE1b, and SE1c sequences (Fig. 5).

The SE2 and SE3 allounits in the Salisbury Embayment belong to Zone DN3. In the Calvert Cliffs they are separated by the PP-0 disconformity of Kidwell (1984) and are exposed at Fairhaven and Chesapeake Beach respectively (Fig. 1). Neither dinocyst nor diatom stratigraphy is able to resolve the hiatus between the SE2 and SE3 allounits and de Verteuil and Norris (1996a) interpreted the PP-0 disconformity as an intrasequence flooding surface. They correlated the combined SE2/SE3 interval with the Kirkwood 2 sequence of Sugar- 
man et al. (1993). My results from the Cape May borehole support correlation respectively of the SE2 and SE3 allounits with the Kw2 $\mathrm{a}^{\prime}$ and Kw2a" sequences as understood herein (Fig. 5). Thus, the PP-0 disconformity in Maryland may after all represent a sequence boundary as thought by Kidwell $(1984 ; 1989)$ and Ward $(1984 ; 1992)$, although genetic interpretations of both it and the Kw2a'/Kw2a" boundary in New Jersey are still being debated. Sr-isotopic ages from SE2 and SE3 in Maryland range from 16.9 to 17.9 m.y. ( \pm 0.6 m.y.; Miller and Sugarman, 1995), in excellent agreement with Kw2a" Srisotopic ages (Miller et al., Chapter 14, this volume; Fig. 4) and with the age calibration of Zone DN3 (de Verteuil and Norris, 1996a).

The DN4, lower DN5, and upper DN5 zonal units discussed above and in de Verteuil and Norris (1996a), permit a straightforward and elegant correlation of the $\mathrm{Kw} 2 \mathrm{~b}, \mathrm{Kw} 2 \mathrm{c}$, and $\mathrm{Kw} 3 \mathrm{a}$ sequences with allounits SE4, SE5, and SE6 (Fig. 5). There is good agreement between Sr-isotopic ages for these units in the Calvert Cliffs (Miller and Sugarman, 1995) and their correlatives in New Jersey as determined from dinocyst stratigraphy. There are some stratigraphic and diagenetic complications in the Maryland strontium data as discussed by Miller and Sugarman (1995), but in general the correlations are superb.

Other middle Miocene allostratigraphic correlations between Maryland and New Jersey are less straightforward, although the basic pattern is clear enough. In New Jersey the Kw3b and Ch1 sequences belong to Zone DN6. In Maryland the conformable Drumcliff and Saint Leonard members of the Choptank belong to Zone DN6, as does a lenticular sand body below the Drumcliff Member informally named the Governor Run Sand by Kidwell (1984). These three units together comprise the SE7 allounit of de Verteuil and Norris (1996a) and Kidwell's CT-0 sequence. Sr-isotopic ages from the Drumcliff Member in Maryland (Miller and Sugarman, 1995) are consistent with the Zone DN6 age calibration from de Verteuil and Norris (1996a). As discussed, however, Sr-isotopic ratios from the Ch1 sequence in the Cape May borehole yielded younger dates that should correspond to lower Zone DN7 (Fig. 2).

Upon first inspection, there does not appear to be any obvious allostratigraphic equivalent to the Kw3b sequence from Cape May in the Maryland Calvert succession. Given the presence and chronostratigraphic position of the Kw3b sequence, however, the stratigraphic relationships of the Governor Run Sand in Maryland acquire added significance. It now seems likely that the regional CT-0 unconformity does not diverge from the base of the Drumcliff Member to include the Governor Run Sand, as interpreted by Kidwell (1984, fig. 7), but instead lies between the Drumcliff and the Governor Run units along a contact that she interpreted as a diastem. The Drumcliff/St. Leonard interval thus constitutes a single, unambiguous transgressive/regressive cycle (sequence) that is here correlated with the Ch1 sequence at Cape May.

The lower, erosional boundary of the Governor Run Sand represents an older unconformity equivalent to the $\mathrm{Kw} 3 \mathrm{a} / \mathrm{Kw} 3 \mathrm{~b}$ contact at Cape May, and the sand itself constitutes the remnant of a separate sequence, rather than a lowstand or early transgressive facies of the Drumcliff/St. Leonards sequence as interpreted by de Verteuil and Norris (1996a; or incised valley fill of the CT-0 sequence, as interpreted by Kidwell, 1984, 1989, 1997). The SE7 allounit is therefore divided here into a lower SE7a sequence and an upper SE7b sequence, which, at the Scientists Cliffs reference section, respectively comprise the Governor Run Sand and the Drumcliff/St. Leonard depositional cycle (Figs. 1,5).

Both the Ch2 sequence and the SE8 allounit belong to Zone DN7 and are clearly broadly correlative. The upper part of the SE8 allounit, however (i.e., Shattuck-beds 20-21), contains some complex stratigraphy near the BGandE site and may comprise more than one depositional sequence (Fig. 1; de Verteuil and Norris, 1996a; Kidwell, 1997). The presence of Achomosphaera andalousiensis in the $\mathrm{Ch} 3$ sequence at Cape May (Table 1), nevertheless indicates that the Ch3 sequence belongs to the upper part of Zone DN9 and so correlates to the SE10 allounit, and not to either the upper SE8 allounit or to the SE9 allounit. Thus, the lower Zone DN8, SE9 allounit (unnamed clay unit of de Verteuil and Norris, 1996a; SM-0 and SM-1 sequences of Kidwell, 1997), which does not contain Achomosphaera andalousiensis (de Verteuil and Norris, 1996a), is apparently not represented in the Cape May borehole (Fig. 5).

Environmental shortening of dinocyst ranges in the upper Miocene of the Cape May borehole (e.g., Hystrichosphaeropsis obscura; Fig. 2) limits the confidence that can be attached to the present, conservative, age model. With this in mind, detailed upper Miocene sequence correlations with the Maryland/Virginia record should perhaps not be belabored. The correlations indicated in Figure 5 follow directly from the present Cape May age model, which adopts a face value interpretation of the dinocyst data, and the Salisbury Embayment upper Miocene age model of de Verteuil and Norris (1996a). Given the chronostratigraphic position of the $\mathrm{Ch} 3$ sequence above the SE9 allounit, it seems reasonable to correlate the $\mathrm{Ch} 3$ sequence and the Ch4 sequence with the SE10 allounit, and the $\mathrm{CH} 3 / \mathrm{Ch} 4$ unconformity with the SM-2' unconformity of Kidwell (1997). Accepting a Zone DN9 or older position for the $\mathrm{Ch} 5$ and $\mathrm{Ch} 6$ sequences, based on the presence of Labyrinthodinium truncatum in upper Ch6, suggests equivalence with the SE11 allounit, which comprises the Windmill Point beds of the Saint Marys Formation. The undated and enigmatic channelized estuarine unit directly overlying the pSM unconformity of Kidwell $(1989,1997)$, and analyzed at the Ranch Club sections south of Little Cove Point by de Verteuil and Norris (1996a), may be an upper Miocene equivalent of the Ch5 sequence. The absence of Barssidinium evangelineae and Operculodinium? eirikianum from the Ch6 sequence, prevents unequivocal correlation with the Windmill Point beds (SE11 allounit), but in view of the marginal marine Ch6 facies at Cape May, this interpretation is nevertheless reasonable (Fig. 5). The alternative hypothesis (not illustrated) is that the entire Ch3-Ch6 interval belongs to Zone DN8 and is equivalent to the SE10 allounit, which thus far, has only been documented in the Ranch Club sections of the Calvert Cliffs (de Verteuil and Norris, 1996a; Kidwell, 1997). The two Zone DN10 sequences of the SE12 allounit (Eastover Formation; Ward and Blackwelder, 1980; Ward, 1992) have not yet been recognized in New Jersey.

\section{SEQUENCE RECORD AND MIOCENE GLACIOEUSTASY}

Some combination of glacioeustasy and regional tectonics is responsible for the punctuated recorded of Miocene sequences on the U.S. Atlantic margin. Basin scale tectonics determined the local accumulation and preservation of Miocene sequences, as shown by dip reversals, uneven thicknesses and patchy distributions (Ward and Blackwelder, 1980; Kidwell, 1984; Ward and Strickland, 1985; Powars et al., 1992; Miller et al., 1996c; de Verteuil and Norris, 1996a, Miller et al., Chapter 14, this volume). Thus, Miller et al. (Chapter 14, this volume) stress that in order to fully sample the New Jersey record of sequences, both strike and dip borehole transects are necessary; de Verteuil and Norris (1996a) had the same realization working in Maryland and Virginia.

Three mechanisms of basin tectonics have been proposed: (1) reactivation of deep faults associated with continental rifting, either by lithospheric compressional stress or flexure (Brown et al., 1972; Mixon and Newell, 1977; Ward and Strickland, 1985; Mixon et al., 1992; de Verteuil and Norris, 1996a); (2) passive crustal flexure in response to sediment loading (Pazzaglia and Gardner, 1994; Miller and Sugarman, 1995; Miller et al., Chapter 14, this volume); (3) crater formation by extra-terrestrial impact and subsequent compensation tectonics and infill sediment loading (Poag et al., 1994; de Verteuil and Norris, 1996a). With the possible exception of intraplate stresses (Cloetingh, 1988), however, these tectonic processes could not generate all the short-duration intrasequence hiatuses that have now been mapped and correlated from the coastal plain to the continental slope 
(papers in this volume and Mountain, Miller, Blum, Poag, and Twichell, 1996).

De Verteuil and Norris $(1992 ; 1996 a)$ compared the record of Miocene sequences in Maryland and Virginia with the Exxon Cycle Chart (Haq et al., 1988), and concluded that second-order glacioeustasy was the dominant control on basin fill history. Other stratigraphers have recently cited evidence for positive correlations between Miocene $\delta^{18} \mathrm{O}$ increases and hiatuses in the New Jersey coastal plain and offshore Baltimore Canyon Trough (Sugarman et al., 1993; Miller and Mountain, 1994; Miller and Sugarman, 1995; Miller, et al., 1996; Miller et al., Chapter 14, this volume). The causal relationship between corrected Oligocene-Miocene $\delta^{18} \mathrm{O}$ maxima, polar ice development and sea-level drawdown, is by now difficult to dispute (e.g., Miller et al., 1991; Wright and Miller, 1992) and suggests a mechanism for the generation of basin-wide unconformities (Posamentier et al., 1988). Because the ages and number of Miocene sequences in the coastal plain are revised herein, and are better constrained than previously, it is important to reevaluate Miller and co-workers' thesis that the Miocene third-order sequence stratigraphy of the middle Atlantic margin is controlled primarily by glacioeustasy.

ODP Site 747 from the Kerguelen Plateau in the southern Indian Ocean, provides one of the best lower through lower upper Miocene $\delta^{18} \mathrm{O}$ records presently available (Wright and Miller, 1992). Oslick et al. (1994) used Sr-isotopic ratios in planktonic foraminifers, and magnetostratigraphy (Heider et al., 1992), to recalibrated the Site 747 $\delta^{18} \mathrm{O}$ record to the CK92 geomagnetic polarity time scale. For the interval between 9-25 m.y. the CK92 and BKSA95 time scales are identical to within \pm 0.1 m.y. so direct comparison of the adjusted Site $747 \delta^{18} \mathrm{O}$ with the Salisbury Embayment/New Jersey sequences is possible (Fig. 5). I also illustrate the ages of major $\delta^{18} \mathrm{O}-$ increaseinflections as determined by Miller et al. (Chapter 14, this volume), based on a stacked and smoothed composite Atlantic benthic foraminiferal $\delta^{18} \mathrm{O}$ record (Wright and Miller, 1994). The offset between $\delta^{18} \mathrm{O}$-increase-inflections in the stacked composite and the Site 747 record (i.e., slightly below the labeled $\delta^{18} \mathrm{O}$ maxima), is between 0.2 and 0.6 m.y. and thus very good (Fig. 5).

The general trend in Miocene $\delta^{18} \mathrm{O}$ values present in the Site 747 data have been well documented globally (e.g. Miller et al., 1987; Woodruff and Savin, 1991). These are (1) a gradual $\sim 0.4 \% \circ \delta^{18} \mathrm{O}$ decrease through the early Miocene; (2) a more rapid $\sim 0.5 \% \circ \delta^{18} \mathrm{O}$ decrease in the latest early Miocene that persisted into the early middle Miocene; (3) a dramatic stepwise $\delta^{18} \mathrm{O}$ increase of $\sim 1.5 \%$ over $\sim 1.5$ m.y. in the early Serravallian; (4) uneven gradual $\sim 0.4 \%$ o $\delta^{18} \mathrm{O}$ increase through the rest of the middle Miocene and into the early late Miocene (Fig. 5). These trends provide a sound proxy for secondorder glacioeustasy in the Miocene and are overprinted by higher frequency, third-order events on the scale of 0.1-1.0 m.y.

Lithostratigraphic and paleontological trends in New Jersey, Maryland, and Virginia are in excellent agreement with the secondorder base level changes inferred from the $\delta^{18} \mathrm{O}$ record. In New Jersey, the Kirkwood Formation deepens upward from the Kw1 sequences to the Kw2 sequences (see above; Miller et al., Chapter 14, this volume); in Maryland the Calvert formation deepens in SE2 and SE3 with respect to SE1. The deepest paleodepths of the Maryland Miocene were attained during deposition of the upper Plum Point Marls and Calvert Beach members of the Calvert Formation (i.e., allounits SE4, SE5, SE6), with maximum depths occurring in the SE5 allounit (Gibson, 1971; Gernant, 1971; Kidwell, 1984; 1989; Ward, 1992; de Verteuil and Norris, 1996a). Preliminary results on benthic foraminiferal biofacies (Miller et al., Chapter 14, this volume), and dinocyst-facies/ palynofacies (de Verteuil, unpubl. data), indicate that the same relationships hold for the Kw2b, Kw2b, and Kw3a sequences.

The sequences deposited during Zone DN6 represent the first transgressions following the major $\sim 15-13 \mathrm{~m} . \mathrm{y} . \delta^{18} \mathrm{O}$ increase (Mi3, Mi4; Fig. 5) and represent dramatic basinward lithofacies shifts in both Maryland and New Jersey. In Maryland the Choptank Formation (SE7, SE8) overlies the Calvert Formation, while in New Jersey the proximal Cohansey Formation overlies the Kirkwood Formation (Ch1, Ch2). Little paleoenvironmental data are available for SE9 (unnamed clay of de Verteuil and Norris, 1996a), although the clay facies and fairly diverse dinocyst assemblages suggest open embayment deposition below normal wave base. However, the inner neritic, wave/tidal-influenced facies of the lower Saint Marys Formation (SE10) are coeval with an additional increase in $\delta^{18} \mathrm{O}$ values (Mi6). In New Jersey at Cape May, the $\mathrm{Ch} 3$ and $\mathrm{Ch} 4$ sequences record shallowing with respect to the underlying $\mathrm{Ch} 2$ and the extensive $\mathrm{Ch} 2 / \mathrm{Ch} 3$ hiatus is commensurate with the magnitude of the Mi5 event (Fig. 5).

There is, therefore, excellent stratigraphic evidence for a direct relationship between second-order glacioeustasy and middle Atlantic coastal plain sequence stratigraphy. While promising, however, correlations between individual coastal plain Miocene sequences and third-order $\delta^{18} \mathrm{O}$ events are less straightforward. There is very good agreement between the Mi6 event and the regionally important middle/upper Miocene unconformity (Fig. 5; Tuscan reflector, Greenlee et al., 1988), and the climactic Mi4 $\delta^{18} \mathrm{O}$ increase is a tightly constrained reference event as described. Importantly, the regressive Mi3a and Mi3b events agree well with the successive shallowing of the Kw2c/SE5, Kw3a/SE6, and Kw3b/SE7a sequences, but the timing is off. The lower Miocene sequences are even less easily interpreted.

This is to be expected: except for the big Kw0/Kw1a and Ch2/ $\mathrm{Ch} 3$ hiatuses, all the other hiatuses are inferred to be less than 1.0 m.y. duration and most are significantly less than 0.5 m.y. duration. Clearly the calibration uncertainties for both the strontium and dinocyst stratigraphy, and the $\delta^{18} \mathrm{O}$ glacioeustasy proxy, are each of the same temporal order as the hiatuses themselves. One finds difficulty, therefore, in avoiding the "event for every occasion" syndrome discussed by Miall (1992).

The Atlantic margin Miocene sequences are nevertheless distinguishable by their fossil content, superposition, and stacking patterns (Walther's Law), so that one to three sequences are bracketed within 1 to 2 m.y. time intervals. Unless one takes the position, therefore, that most or all of these sequences are of an order of magnitude shorter duration $(\sim 10,000-50,000 \mathrm{yr})$, so that roughly $90 \%$ of the coastal plain Miocene is without record, one must accept the conclusion that these unconformity-bound sequences are indeed temporally correlative from site to site. Two lines of evidence further indicate that the middle Atlantic margin Miocene record comprises third-order sequences (0.1-1.0 m.y. duration). First, the incremental increase of strontium ratios within individual sequences is compelling evidence for their extended duration, based on comparisons with strontium regressions from continuous oceanic records (Miller et al., 1991; Oslick et al., 1994; Figs. 2, 3). Second, consistent stacking patterns over several biozones (i.e., second-order transgression/regression trends) would not be observed at multiple sites if individual records consisted of randomly preserved fourth- and fifth-order events.

This line of reasoning supports the view that a limited number of third-order events, synchronous to within 50,000 yr, were responsible for the development of an equal number of margin-wide unconformities. A few events of this scale have been identified in Atlantic $\delta^{18} \mathrm{O}$ records and are convincingly argued to be associated with periods of Antarctic polar ice buildup (Wright and Miller, 1992; Fig. 5). The clear relationship between Miocene second-order $\delta^{18} \mathrm{O}$ fluctuations and Atlantic margin stratigraphy, strongly supports the postulated link between sequence development and glacioeustasy. At present, however, there are more third-order Miocene sequences on the middle Atlantic margin than there are recognized significant $(\sim 0.5 \%)$ $\delta^{18} \mathrm{O}$ increases; conversely, in most $\delta^{18} \mathrm{O}$ records there are more smaller scale increases $(\sim 0.2 \%$ o $)$ than preserved third-order sequences (Fig. 5). Because not all the minor $\delta^{18} \mathrm{O}$ increases produced basinscale stratigraphic sequences, either more detailed $\delta^{18} \mathrm{O}$ records are needed to identify additional "significant" events, or additional elements, such as intraplate stresses, were contributing to third-order base-level changes. Thus, although the present results point towards the paramountcy of glacioeustasy as a driving mechanism of Mio- 
cene sequence architecture, they cannot confirm a straightforward causal link between Miocene glacioeustasy and third-order sequence development. In view of its obvious rational appeal and the clear limitations to our present chronostratigraphic resolution, there remains, however, strong incentive to pursue this theory.

\section{CONCLUSIONS}

In this study, I integrated dinocyst and Sr-isotopic stratigraphy from the Cape May and Atlantic City boreholes to delineate and develop a chronology for 16 Miocene sequences in New Jersey. For the lower and lower middle Miocene, there is excellent agreement between dinocyst stratigraphy calibrated to the BKSA95 time scale and the independent Sr-isotopic ages (Figs. 2, 3). Sr-isotopic ages from the upper middle Miocene (Zones DN6 and DN7) are consistently younger than those determined from the dinocyst calibrations of de Verteuil and Norris (1996a). I attribute this almost entirely to unresolved magnetostratigraphic and biostratigraphic problems in global geochronology during this interval. Dinocyst stratigraphy provides the only age control for the upper Miocene in New Jersey.

The upper four Cape May sequences represent the first confirmed upper Miocene units in New Jersey; their estuarine/fluvio-deltaic character appear to date the early stages in the development of the Delaware River system. On the other hand, the Kw0 sequence is the oldest Neogene unit recorded to date from the middle Atlantic margin and likely represents a depositional response to the basal Miocene transgression. Possibly only two major hiatuses (>1.0 m.y.) are present in the combined record from both boreholes: the first, $\mathrm{Kw} 0 /$ Kw la hiatus, corresponds to a prolonged $\delta^{18} \mathrm{O}$ increase leading up to the Mila event; the second, Ch2/Ch3 hiatus, is due to depleted accommodation at the close of the middle Miocene and forced regression associated with the high-magnitude Mi5 event.

Regional dinocyst stratigraphy developed by de Verteuil and Norris (1996a) permits the first detailed Miocene sequence correlations between deltaic facies in New Jersey and neritic coastal embayment facies in Maryland, Virginia and Delaware (Fig. 5). A total of 19 Miocene sequences are documented from the middle Atlantic coastal plain. The poor lower lower Miocene record in the Salisbury Embayment is balanced by preservation in the upper Miocene. There is, however, excellent agreement in the number and timing of sequences in the two depositional systems, with the $\mathrm{Kw} 0 / \mathrm{Kw} 1 \mathrm{a}$ hiatus (22.2-20.8 m.y.) representing the only major break in the combined succession. Locally, tectonically controlled erosion or accommodation affects individual sections, so that although some localities contain expanded records for individual sequences, no sections contain all sequences. This tectonic overprinting, however, cannot mask the punctuated record of sequences, separated by short-duration hiatuses $(0.1-0.5$ m.y.), which characterizes the Miocene of this margin.

The Salisbury Embayment and New Jersey depositional systems both show excellent correlation in timing and magnitude with second-order glacioeustatic trends inferred from $\delta^{18} \mathrm{O}$ stratigraphy. Although some ties seem clear enough, correlations between third-order sequences and the $\delta^{18} \mathrm{O}$ record are hampered, on both sides, by calibration and resolution problems. The punctuated record of sequences that are relatively independent of sediment supply, separated by margin-wide erosional unconformities, is nevertheless best explained as a third-order glacioeustatic effect.

\section{ACKNOWLEDGMENTS}

The author thanks colleagues on the New Jersey Transect Project for sharing their ideas and early results with him by way of preprints from this volume. I am particularly grateful to James Browning and Stephen Pekar (both Rutgers University) for sampling the Cape May and Atlantic City cores on my behalf, and to Kenneth Miller (Rutgers
University) for his co-operation and guidance in planning and undertaking this research. Viorica Nicolae skillfully processed the samples, for which I am most grateful. The manuscript benefited from a reviews by Susan Kidwell (University of Chicago) and Kenneth Miller and from comments by Peter Sugarman (New Jersey Geological Survey). Research funding was provided by the National Sciences and Engineering Research Council of Canada operating grant to Geoffrey Norris (University of Toronto). A post-doctoral stipend for the author was provided by consortium funding from Amoco, Chevron, Exxon, and Unocal and is gratefully acknowledged. Consortium research is coordinated by William Berggren (Woods Hole Oceanographic Institution), whose support for this work is appreciated and acknowledged.

\section{REFERENCES}

Andrews, G.W., 1988. A revised marine diatom zonation for the Miocene strata of the southeastern United States. Geol. Surv. Prof. Pap. U.S., 1481:1-29.

Aubry, M.-P., 1993. Calcareous nannofossil stratigraphy of the Neogene formations of Jamaica. In Robinson, E. R., and Wright, R. M. (Eds.), Biostratigraphy of Jamaica, Mem.-Geol. Soc. Am., 182:131-178.

Berggren, W.A., 1993. Neogene planktonic foraminiferal biostratigraphy of eastern Jamaica. In Robinson, E.R., and Wright, R.M. (Eds.), Biostratigraphy of Jamaica, Mem.-Geol. Soc. Am., 182:179-217.

Berggren, W.A., Kent, D.V., Swisher, C.C., III, and Aubry, M.-P., 1995. A revised Cenozoic geochronology and chronostratigraphy. In Berggren, W.A., Kent, D.V., Aubry, M.-P., and Hardenbol, J. (Eds.), Geochronology, Time Scales and Global Stratigraphic Correlation. Spec. Publ.Soc. Econ. Paleontol. Mineral., 54:129-212.

Brinkhuis, H., Powell, A.J., and Zevenboom, D., 1992. High-resolution dinoflagellate cyst stratigraphy of the Oligocene/Miocene transition interval in northwest and central Italy. In Head, M.J., and Wrenn, J.H. (Eds.), Neogene and Quaternary Dinoflagellate Cysts and Acritarchs: Am. Assoc. Stratigr. Palynol. Found., 219-258.

Brown, P.M., Miller, J.A., and Swain, F.M., 1972. Structural and stratigraphic framework, and spatial distribution of permeability of the Atlantic Coastal Plain, North Carolina to New York. Geol. Surv. Prof. Pap. U.S., 796:1-79.

Cande, S.C., and Kent, D.V., 1992. A new geomagnetic polarity time scale for the Late Cretaceous and Cenozoic. J. Geophys. Res., 97:13,91713,951

Cloetingh, S., 1988. Intraplate stresses: a new element in basin analysis. In Kleinspehn, K.L., and Paola, C. (Eds.), New Perspectives of Basin Analysis: New York (Springer-Verlag), 205-230.

de Verteuil, L., 1996. Data Report: Upper Cenozoic dinoflagellate cysts from the continental slope and rise off New Jersey. In Mountain, G.S., Miller, K.G., Blum, P., Poag, C.W., and Twichell, D.C. (Eds.), Proc. ODP, Sci. Results, 150: College Station, TX (Ocean Drilling Program), 439-454.

de Verteuil, L., and Edwards, L.E., 1992. Palynology of selected samples from the Belleplain Core, Cape May County, New Jersey: U.S. Dept. Int. Geol. Surv. Rept. on Referred Fossils (on file at Paleontology and Stratigraphy Branch, Reston, Va).

de Verteuil, L., and Norris, G., 1992. A new dinoflagellate cyst sequence biostratigraphic framework for the Miocene of the Baltimore Canyon Trough and adjacent Salisbury Embayment. In Lidgard, S., and Crane, P. R. (Eds.), Fifth North American Paleontological Convention-Abstracts and Program, Paleontol. Soc., 299.

, 1996a. Part I: Dinoflagellate cyst zonation and allostratigraphy of the Chesapeake Group. In de Verteuil, L., and Norris, G., Miocene dinoflagellate stratigraphy and systematics of Maryland and Virginia, Micropaleontol. Suppl. 1996, 42:1-82.

1996b. Part II: Homology and structure in dinoflagellate cyst terminology. In de Verteuil, L., and Norris, G., Miocene dinoflagellate stratigraphy and systematics of Maryland and Virginia, Micropaleontol. Suppl. 1996, 42:83-153.

1996c. Upper Miocene Geonettia clineae gen. et sp. nov., an opportunistic coastal embayment dinoflagellate of the Homotryblium Complex. Micropaleontology, 42:263-284.

Gernant, R.E., 1971. Invertebrate biofacies and paleoenvironments. In Gernant, R.E., Gibson, T.G., and Whitmore, F.C.J. (Eds.), Environmental History of Maryland Miocene: Baltimore (Maryland Geological Survey), 19-30. 
Gibson, T.G., 1971. Miocene of the middle Atlantic Coastal Plain. In Gernant, R.E., Gibson, T.G., and Whitmore, F.C.J. (Eds.), Environmental History of Maryland Miocene: Baltimore (Maryland Geological Survey), $1-15$.

Greenlee, S.M., Devlin, W.J., Miller, K.G., Mountain, G.S., and Flemings, P. B., 1992. Integrated sequence stratigraphy of Neogene deposits, New Jersey continental shelf and slope: comparison with the Exxon model. Geol. Soc. Am. Bull., 104:1403-1411.

Greenlee, S.M., Schroeder, F.W., and Vail, P.R., 1988. Seismic stratigraphic and geohistory analysis of Tertiary strata from the continental shelf off New Jersey: calculation of eustatic fluctuations from stratigraphic data. In Sheridan, R.E., and Grow, J.A. (Eds.), The Atlantic Continental Margin. Geol Soc. Am., Geol. North Am. Ser., 437-444.

Haq, B.U., Hardenbol, J., and Vail, P.R., 1988. Mesozoic and Cenozoic chronostratigraphy and cycles of sea-level change. In Wilgus, C.K., Hastings, B.S., St. C. Kendall, C.G.St.C., Posamentier, H.W., Ross, C.A., and Van Wagoner, J.C. (Eds.), Sea-Level Changes-An Integrated Approach. Spec. Publ.-Soc. Econ. Paleontol. Mineral., 42:72-108.

Heider, F., Leitner, B., and Inokuchi, H., 1992. High southern latitude magnetostratigraphy and rock magnetic properties of sediments from Sites 747, 749, and 751. In Wise, S.W., JR., Schlich, R., et al., Proc. ODP, Sci. Results, 120: College Station, TX (Ocean Drilling Program), 225-245.

Kidwell, S.M., 1984. Outcrop features and origin of basin margin unconformities in the Lower Chesapeake Group (Miocene), Atlantic Coastal Plain. In Schlee, J.S. (ed.), Interregional unconformities and hydrocarbon accumulation: AAPG Mem., 36. Tulsa (American Association of Petroleum Geologists), 37-58.

, 1989. Stratigraphic condensation of marine transgressive records: origin of major shell deposits in the Miocene of Maryland. J. Geol., 97:1-24.

, 1997. Anatomy of extremely thin marine sequences landward of a passive-margin hinge zone: Neogene Calvert Cliffs succession, Maryland. J. Sed. Res., 67B:322-340.

Miall, A.D., 1992. Exxon global cycle chart: an event for every occasion? Geology, 20:787-790.

Miller, K.G., et al., 1994a. Proc. ODP, Init. Repts., 150X: College Station, TX (Ocean Drilling Program).

, 1996a. Proc. ODP, Init. Repts., 150X (Suppl.): College Station, TX (Ocean Drilling Program).

Miller, K.G., Fairbanks, R.G., and Mountain, G.S., 1987. Tertiary oxygen isotope synthesis, sea-level history, and continental margin erosion. Paleoceanography, 2:1-19.

Miller, K.G., Feigenson, M.D., Wright, J.D., and Clement, B.M., 1991. Miocene isotope reference section, Deep Sea Drilling Project Site 608: An evaluation of isotope and biostratigraphic resolution. Paleoceanography, 6:33-52.

Miller, K.G., Liu, C., and Feigenson, M.D., 1996b. Oligocene to middle Miocene Sr-isotopic stratigraphy of the New Jersey continental slope. In Mountain, G.S., Miller, K.G., Blum, P., Poag, C.W., and Twichell, D.C. (Eds.), Proc. ODP, Sci. Results, 150: College Station, TX (Ocean Drilling Program), 97-114.

Miller, K.G., and Mountain, G.S., 1994. Global sea-level change and the New Jersey margin. In Mountain, G.S., Miller, K.G., Blum, P., et al., Proc. ODP, Init. Repts., 150: College Station, TX (Ocean Drilling Program), $11-20$.

Miller, K.G., Mountain, G.S., Blum, P., Gartner, S., Alm Per, G., Aubry, M.P., Burckle, L.H., Guerin, G., Katz, M.E., Christensen, B.A., Compton, J., Damuth, J.E., Deconinck, J.F., de Verteuil, L., Fulthorpe, C.S., Hesselbo, S.P., Hoppie, B.W., Kotake, N., Lorenzo, J.M., McCracken, S., McHugh, C.M., Quayle, W.C., Saito, Y., Snyder, S.W., ten Kate, W.G., Urbat, M., Van Fossen, M.C., Vecsei, A., Sugarman, P.J., Mullikin, L., Pekar, S., Browning, J.V., Liu, C., Feigenson, M.D., Goss, M., Gwynn, D., Queen, D.G., Powars, D.S., Heibel, T.D., and Bukry, D., 1996c. Drilling and dating New Jersey Oligocene-Miocene sequences: Ice volume, global sea level, and Exxon records. Science, 271:1092-1095.

Miller, K.G., and Sugarman, P. J., 1995. Correlating Miocene sequences in onshore New Jersey boreholes (ODP Leg 150X) with global $\delta^{18} \mathrm{O}$ and Maryland outcrops. Geology, 23:747-750.

Miller, K.G., Wright, J.D., Van Fossen, M., and Kent, D.V., 1994b. Miocene stable isotopic stratigraphy and magnetostratigraphy of Buff Bay, Jamaica. Geol. Soc. Am. Bull., 106:1605-1620.
Mixon, R.B., and Newell, W.L., 1977. Stafford fault system: structures documenting Cretaceous and Tertiary deformation along the Fall Line in northeastern Virginia. Geology, 5:437-440.

Mixon, R.B., Powars, D.S., and Daniels, D.L., 1992. Nature and timing of deformation of upper Mesozoic and Cenozoic deposits in the inner Atlantic Coastal Plain, Virginia and Maryland. In Gohn, G.S. (Ed.), Proc. 1988 USGS Workshop Geol. Geohydrol. Atlantic Coastal Plain, USGS Circ., 1059:63-73.

Mountain, G.S., Miller, K.G., Blum, P., et al., 1994. Proc. ODP, Init. Repts. 150: College Station TX (Ocean Drilling Program).

Mountain, G.S., Miller, K.G., Blum, P., Poag, C.W., and Twichell, D.C. (Eds.), 1996. Proc. ODP, Sci. Results, 150: College Station, TX (Ocean Drilling Program).

Oslick, J.S., Miller, K.G., Feigenson, M.D., and Wright, J.D., 1994. Oligocene-Miocene strontium isotopes: stratigraphic revisions and correlations to an inferred glacioeustatic record. Paleoceanography, 9:427-443.

Pazzaglia, F.J., and Gardner, T.W., 1994. Late Cenozoic flexural deformation of the middle U.S. passive margin. J. Geophys. Res., 99:143-157.

Poag, C.W., Powars, D.S., Poppe, L.J., and Mixon, R.B., 1994. Meteoroid mayhem in Ole Virginny: source of the North American tektite strewn field. Geology, 22:691-694.

Posamentier, H.W., Jervey, M.T., and Vail, P.R., 1988. Eustatic controls on clastic deposition, I. Conceptual framework. In Wilgus, C.K., Hastings, B.S., Ross, C.A., Posamentier, H.W., Van Wagoner, J., and Kendall, C.G.St.C. (Eds.), Sea-Level Changes: An Integrated Approach. Spec. Publ.-Soc. Econ. Paleontol. Mineral., 42:109-124.

Powars, D.S., Mixon, R.B., and Bruce, S., 1992. Uppermost Mesozoic and Cenozoic geologic cross section, outer coastal plain of Virginia. In Gohn, G.S. (Ed.), Proc. 1988 USGS Workshop Geol. Hydrol. Atlantic Coastal Plain, USGS Circ., 1059:85-101.

Sugarman, P.J., Miller, K.G., Owens, J.P., and Feigenson, M.D., 1993. Strontium isotope and sequence stratigraphy of the Miocene Kirkwood Formation, southern New Jersey. Geol. Soc. Am. Bull., 105:423-436.

Wall, D., Dale, B., Lohmann, G.P. and Smith, W.K., 1977. The environmental and climatic distribution of dinoflagellate cysts in modern marine sediments from regions in the North and South Atlantic Oceans and adjacent seas. Mar. Micropaleontol., 2:121-200.

Ward, L.W., 1984. Stratigraphy of outcropping Tertiary beds along the Pamunkey River-Central Virginia Coastal Plain. In Ward, L.W., and Krafft, K. (Eds.), Stratigraphy and Paleontology of the Outcropping Beds in the Pamunkey River Region, Central Virginia Coastal Plain: Guidebook for Atlantic Coastal Plain Geological Association, 1984 Field Trip. Atlantic Coastal Plain Geol. Assoc., 11-78.

1992. Molluscan biostratigraphy of the Miocene, Middle Atlantic Coastal Plain of North America: Virginia Museum of Natural History Memoir, 2. Martinsville (Virginia Museum of Natural History).

Ward, L.W., and Blackwelder, B.W., 1980. Stratigraphic revision of upper Miocene and lower Pliocene beds of the Chesapeake Group, middle Atlantic Coastal Plain. USGS Bull., 1482-D.

Ward, L.W., and Strickland, G.L., 1985. Outline of Tertiary stratigraphy and depositional history of the U.S. Atlantic Coastal Plain. In Poag, C.W. (Ed.), Geologic Evolution of the United States Atlantic Margin: New York (Van Nostrand Reinhold), 87-123.

Woodruff, F., and Savin, S.M., 1991. Mid-Miocene isotope stratigraphy in the deep sea: high-resolution correlations, paleoclimatic cycles, and sediment preservation. Paleoceanography, 6:755-806.

Wright, J.D., and Miller, K.G., 1992. Miocene stable isotope stratigraphy, Site 747, Kerguelen Plateau. In Wise, S.W., Jr., Schlich, R., et al., Proc. ODP, Sci. Results, 120: College Station, TX (Ocean Drilling Program), $855-866$

, 1993. Southern Ocean influences on Late Eocene to Miocene deep-water circulation. In Kennett, J.P., and Warnke, D.A. (Eds.), The Antarctic Paleoenvironment: A Perspective on Global Change. Antarct. Res. Ser., 60:1-25.

Date of initial receipt: 16 August 1996

Date of acceptance: 13 January 1997

Ms 150XSR-310 